\title{
Soil carbon dioxide and methane fluxes from forests and other land use types in an African tropical montane region
}

\author{
I. Wanyama - D. E. Pelster $\cdot$ K. Butterbach-Bahl $\cdot$ L. V. Verchot $\cdot$ \\ C. Martius • M. C. Rufino
}

Received: 20 June 2018/ Accepted: 21 February 2019/Published online: 28 February 2019

(C) The Author(s) 2019

\begin{abstract}
In the last 40 years, large areas of the Mau forest, the largest contiguous tropical montane forest in East Africa, have been cleared for agriculture. To date, there are no empirical data on how this land use change affects carbon dioxide $\left(\mathrm{CO}_{2}\right)$ fluxes from soil respiration and soil methane $\left(\mathrm{CH}_{4}\right)$ fluxes. This study reports measured annual soil $\mathrm{CO}_{2}$ and $\mathrm{CH}_{4}$ fluxes from the native Mau forest and previously forested lands converted to smallholder grazing land, smallholder and commercial tea plantations and eucalyptus plantations. Fluxes were measured weekly from August 2015 to August 2016 using the static chamber method. Grazing lands had the highest $(\mathrm{p}=0.028)$ cumulative respiratory $\mathrm{CO}_{2}$ fluxes $\left(25.6 \pm 2.9 \mathrm{Mg} \mathrm{CO}_{2}-\mathrm{C}\right.$ ha ${ }^{-1}$ year $^{-1}$ ), whereas lowest fluxes were observed in commercial tea plantations $\left(5.6 \pm 0.5 \mathrm{Mg} \mathrm{CO} \mathrm{CO}_{2}-\mathrm{C}\right.$ $\mathrm{ha}^{-1}$ year $^{-1}$ ). Soil respiratory $\mathrm{CO}_{2}$ fluxes were
\end{abstract}

Responsible Editor: Karsten Kalbitz

I. Wanyama - C. Martius

Center for International Forestry Research (CIFOR),

PO Box 30677, Nairobi 00100, Kenya

D. E. Pelster · K. Butterbach-Bahl

International Livestock Research Institute (ILRI),

PO Box 30709, Nairobi 00100, Kenya

M. C. Rufino (ه)

Lancaster Environment Centre, Lancaster University,

Lancaster LA1 4YQ, UK

e-mail: m.rufino1@lancaster.ac.uk positively correlated with soil $\mathrm{pH}$, but negatively correlated with soil C:N ratio. Annual soil fluxes were explained by soil $\mathrm{pH}$, bulk density and the interaction between soil $\mathrm{pH}$ and $\mathrm{C}: \mathrm{N}$ ratio. Most soils were sinks for atmospheric $\mathrm{CH}_{4}$ across all land use types. Methane uptake was highest for native forest sites $\left(-3.08 \pm 0.35\right.$ to $-5.84 \pm 0.61 \mathrm{~kg} \mathrm{CH}_{4}-\mathrm{C} \mathrm{ha}^{-1}$ year $\left.^{-1}\right)$ and for eucalyptus plantations $\left(-3.43 \pm 0.19 \mathrm{~kg} \mathrm{CH}_{4}-\mathrm{C} \mathrm{ha}{ }^{-1}\right.$ year $\left.^{-1}\right)$. Uptake decreased significantly with increasing land use intensity (smallholder tea plantations: $-1.42 \pm 0.09 \mathrm{~kg} \mathrm{CH}_{4}-\mathrm{C} \mathrm{ha}^{-1}$ year $^{-1}$, commercial tea plantations: $-1.44 \pm 0.29 \mathrm{~kg} \quad \mathrm{CH}_{4}-\mathrm{C} \quad \mathrm{ha}^{-1}$ year ${ }^{-1}$ ). Soils of smallholder grazing lands had the lowest $\mathrm{CH}_{4}$ uptake rates $\left(-0.36 \pm 0.25 \mathrm{~kg} \mathrm{CH}_{4}-\mathrm{C}\right.$ ha $^{-1}$ year $\left.{ }^{-1}\right)$. Annual $\mathrm{CH}_{4}$ uptake was negatively correlated with mean annual soil water-filled pore space $(\mathrm{p}<0.01)$ and bulk density $(\mathrm{p}=0.003)$ and decreased with increasing soil inorganic $\mathrm{NH}_{4}{ }^{+}$

K. Butterbach-Bahl

Institute of Meteorology and Climate Research,

Atmospheric Environmental Research (IMK-IFU),

Karlsruhe Institute of Technology, Kreuzeckbahnstr, 19,

82467 Garmisch-Partenkirchen, Germany

L. V. Verchot

International Centre for Tropical Agriculture (CIAT),

Cali, Colombia

D. E. Pelster

Agriculture and Agri-Food Canada, 2560 Blvd

Hochelaga, Quebec City, Canada 
concentrations $(\mathrm{p}=0.03)$. Annual soil $\mathrm{CH}_{4}$ can be explained by mainly soil water content and bulk density and these factors are related to gas diffusion. Our study shows that converting tropical montane forests to managed land use types affects soil $\mathrm{CO}_{2}$ and $\mathrm{CH}_{4}$ fluxes. Specifically, the $\mathrm{CH}_{4}$ sink strength in managed land use types of these montane tropical soils was reduced to less than half of the sink strength in the native forest. Soil respiratory $\mathrm{CO}_{2}$ fluxes were also altered by land use with grazing lands emitting 3-4 times more $\mathrm{CO}_{2}$ than the other land use types.

Keywords Deforestation - Kenya - GHG emissions · Fertilisers · Livestock

\section{Introduction}

Soil respiration is one of the dominant fluxes in the global carbon cycle (Adachi et al. 2017). Hashimoto et al. (2015) estimated that the mean annual $\mathrm{CO}_{2}$ fluxes from soils to the atmosphere between 1965 and 2012 were $91 \mathrm{Pg} \mathrm{C}$ year $^{-1}$, of which $64 \%$ originate from tropical regions. Soil respiration can be broken down into two processes: organic matter mineralisation by soil microbes (heterotrophic respiration) and root respiration (autotrophic respiration) (Bond-Lamberty et al. 2004). The relative contribution of autotrophic and heterotrophic soil respiration varies between land use types and seasons (Arevalo et al. 2010; Hanson et al. 2000). Soil respiration typically increases with increasing temperature as long as soil moisture, aeration and supply of easily degradable soil carbon compounds are not limiting (Davidson and Jansen 2006).

Soils are also the largest terrestrial sink of atmospheric methane $\left(\mathrm{CH}_{4}\right)$ (Dutaur and Verchot 2007). Global $\mathrm{CH}_{4}$ uptake by upland soils has been estimated to range from 9 to $51 \mathrm{Tg} \mathrm{CH}_{4}$ year ${ }^{-1}$ (Dutaur and Verchot 2007; Ghosh et al. 2015; Kirschke et al. 2013), with tropical forest and grassland soils contributing approximately 58\% to this uptake (Yu et al. 2017). $\mathrm{CH}_{4}$ fluxes of upland soils are the result of two processes: methanogenesis (production) under anaerobic conditions and methanotrophy (consumption/ oxidation) in aerobic soils (Trotsenko and Khmelenina 2002). Depending on soil aeration, upland soils can act as a sink or source of $\mathrm{CH}_{4}$. Gas diffusion into the soil is affected by soil water content and soil texture and these two factors have been regarded as primary controls of $\mathrm{CH}_{4}$ uptake in upland soil ecosystems (Verchot et al. 2000). In upland forest soils, soil conditions favour the activity and growth of methanotrophs and therefore the methane oxidation process is dominant compared to production (Kravchenko 2017), as a result forests soils usually act as methane sinks. Soil tillage or animal trampling, typically associated with agriculture, can affect soil properties such as bulk density (Owuor et al. 2018), which in turn reduces soil pore size and connectivity (Dexter 2004) and thus, gas diffusivity. This reduction in diffusivity can then cause lower $\mathrm{CH}_{4}$ uptake compared to soils of natural ecosystems (Jacinthe et al. 2014). It has often been reported that the conversion of natural forests to managed land use types reduces soil methane uptake (Oertel et al. 2016).

Another factor affecting methanotrophic activity in soils is the availability of inorganic nitrogen $(\mathrm{N})$. For instance, Wolf et al. (2012) reported that in a tropical montane forest in southern Ecuador, $\mathrm{CH}_{4}$ uptake was limited by ammonium $\left(\mathrm{NH}_{4}{ }^{+}\right)$and nitrate $\left(\mathrm{NO}_{3}{ }^{-}\right)$ availability. Comparable results were also found for methanotrophic activity in soils of tropical lowland forests in Indonesia and Panama, where methane uptake also increased with increasing $\mathrm{NH}_{4}{ }^{+}$and $\mathrm{NO}_{3}{ }^{-}$ availability (Veldkamp et al. 2013; Hassler et al. 2015). These studies indicate that $\mathrm{CH}_{4}$ uptake in tropical soils can be limited by $\mathrm{N}$ availability. In contrast, other studies show a reduction in $\mathrm{CH}_{4}$ uptake capacity with increasing soil $\mathrm{NH}_{4}{ }^{+}$concentrations at temperate forest sites affected by high rates of atmospheric $\mathrm{N}$ deposition (Bédard and Knowles 1989; Butterbach-Bahl and Papen 2002). This can be explained by osmotic stress by $\mathrm{NH}_{4}{ }^{+}$salts and by competitive inhibition of the methane mono-oxygenase due to its capability to also oxidise $\mathrm{NH}_{4}{ }^{+}$to nitrite. Moreover, intermediate and end products of the latter process, hydroxylamine and nitrite, are toxic for methanotrophs, which also leads to a reduction of $\mathrm{CH}_{4}$ oxidation in soils (Bodelier and Laanbroek 2004).

In Sub-Saharan Africa, measurements of soil $\mathrm{CO}_{2}$ and $\mathrm{CH}_{4}$ fluxes remain limited to approximately 30 studies in natural ecosystems (forests and grassland) and about 26 studies in agricultural lands (Kim et al. 2016). Moreover, only one study (Pelster et al. 2017), measured fluxes from a number of land use types that are typical of the heterogeneous landscape of the East 
African highlands, while none of these studies compared $\mathrm{CO}_{2}$ and $\mathrm{CH}_{4}$ fluxes from different land use types to the native forests. This hampers our ability to understand how changes in land use in tropical African highlands affect soil $\mathrm{CO}_{2}$ and $\mathrm{CH}_{4}$ fluxes. Thus this area needs to be explored to improve our understanding of the $\mathrm{CO}_{2}$ and $\mathrm{CH}_{4}$ dynamics accompanying these changes. The Mau-forest complex is the largest closed-canopy montane forest in East Africa, and provides several ecological services such as provision of water for a number of lakes in Kenya, and acting as a biodiversity reserve. However, large areas of forest have been cleared for arable land, grasslands, tea and tree plantations (Baldyga et al. 2008; Blackie 1972; Kinyanjui 2009; Olang et al. 2014). As a result, the forest area decreased by approximately $34 \%$ between 1986 and 2009 (Hesslerova and Pokorny 2010). Land use change from natural forest to managed land use results in changes in vegetation type (litter quality), soil microbial community structure, and soil physicochemical properties (Chiti et al. 2018). These factors interact in complex ways to influence soil GHG fluxes through moderation of plant and soil microbial activity and these effects may vary from site to site (Smith et al. 2018). The Mau Forest presents an excellent landscape to explore how changes associated with land use affect soil $\mathrm{CO}_{2}$ and $\mathrm{CH}_{4}$ fluxes and to understand the underlying mechanisms that result in these changes. Therefore, the objectives of this study were to (1) quantify the annual soil respiratory $\mathrm{CO}_{2}$ and $\mathrm{CH}_{4}$ fluxes from natural forest and compare them to managed land use types (tea, grazing land, and tree plantations), and (2) assess the factors affecting spatial and temporal variability of soil respiration and $\mathrm{CH}_{4}$ fluxes from forests and managed land. We hypothesized that the highest rates of soil respiration and oxidation of atmospheric $\mathrm{CH}_{4}$ would be found at the natural forest, and that grassland and tea plantation soils would have the lowest $\mathrm{CH}_{4}$ uptake rates as a result of the changes in soil properties, vegetation, and management. We evaluated hypotheses related to the effects of temperature and soil water content on these fluxes and assessed the importance of soil $\mathrm{pH}$ and nitrogen availability on soil $\mathrm{CO}_{2}$ and $\mathrm{CH}_{4}$ fluxes.

\section{Materials and methods}

Study area and experimental design

The study area was located in the southwest Mau Forest in Western Kenya at approximately 2200 m above sea level. During the study period (August 2015 to August 2016) annual rainfall was $2050 \mathrm{~mm}$, while the mean annual air temperature was $16.6 \pm 3.9^{\circ} \mathrm{C}$ (Wanyama et al. 2018). The rainfall pattern at the study site is bimodal. The first rainy season is typically between April and July, and the second from October to December. During the study period there were sporadic rains during the dry seasons, and dry periods during the rainy seasons.

The study was carried out at two separate agricultural sites with adjacent natural forests. A smallholder site at Chepsir $\left(0^{\circ} 17^{\prime} 41^{\prime \prime} \mathrm{S}, 35^{\circ} 25^{\prime} 4^{\prime \prime} \mathrm{E}\right)$ with the major agricultural land use types being pasture (Pennisetum clandestinum Hochst. ex Chiov) and tea plantations smaller than 0.5 ha. The second site was a commercial tea estate at Kapkatugor $\left(0^{\circ} 19^{\prime} 01^{\prime \prime} \mathrm{S}, 35^{\circ} 23^{\prime \prime} \mathrm{E}\right)$, with land use dominated by large scale ( $>10$ ha) tea and eucalyptus plantations. We selected three blocks at each site; each block comprised one replicate of each of the major land use types at each respective site (Fig. 1). The major land use types at the tea estate site were forest (TEF1, TEF2 and TEF3), tea plantations (TET1, TET2 and TET3) and eucalyptus plantations (TEP1, TEP2 and TEP3). At the smallholder site, forest (SHF1, SHF2, and SHF3), grazing land (SHG1, SHG2 and SHG3) and tea plantations (SHT1, SHT2 and SHT3) were the major land use types. Detailed information was reported by Wanyama et al. (2018) and is also presented in Table 7 in Appendix. The landscape of the study site is undulating and can be divided into lower, mid and crest slope positions: the forest sites were on one side of a valley while the converted land use types were on the other side. We established the plots at the same slope position where the gradient was uniform and used a high precision GPS to measure elevation. Therefore slope position and gradient, and elevation of the replicates were kept consistent within each site. Soils were also uniform as observed from the consistent red colour and texture of subsoil; these are classified as Andic Humic Nitisols (IUSS Working Group WRB 2015).

We carried out an inventory of the tree species and biomass in the forest plots at our sites. We used a $20 \mathrm{~m}$ 

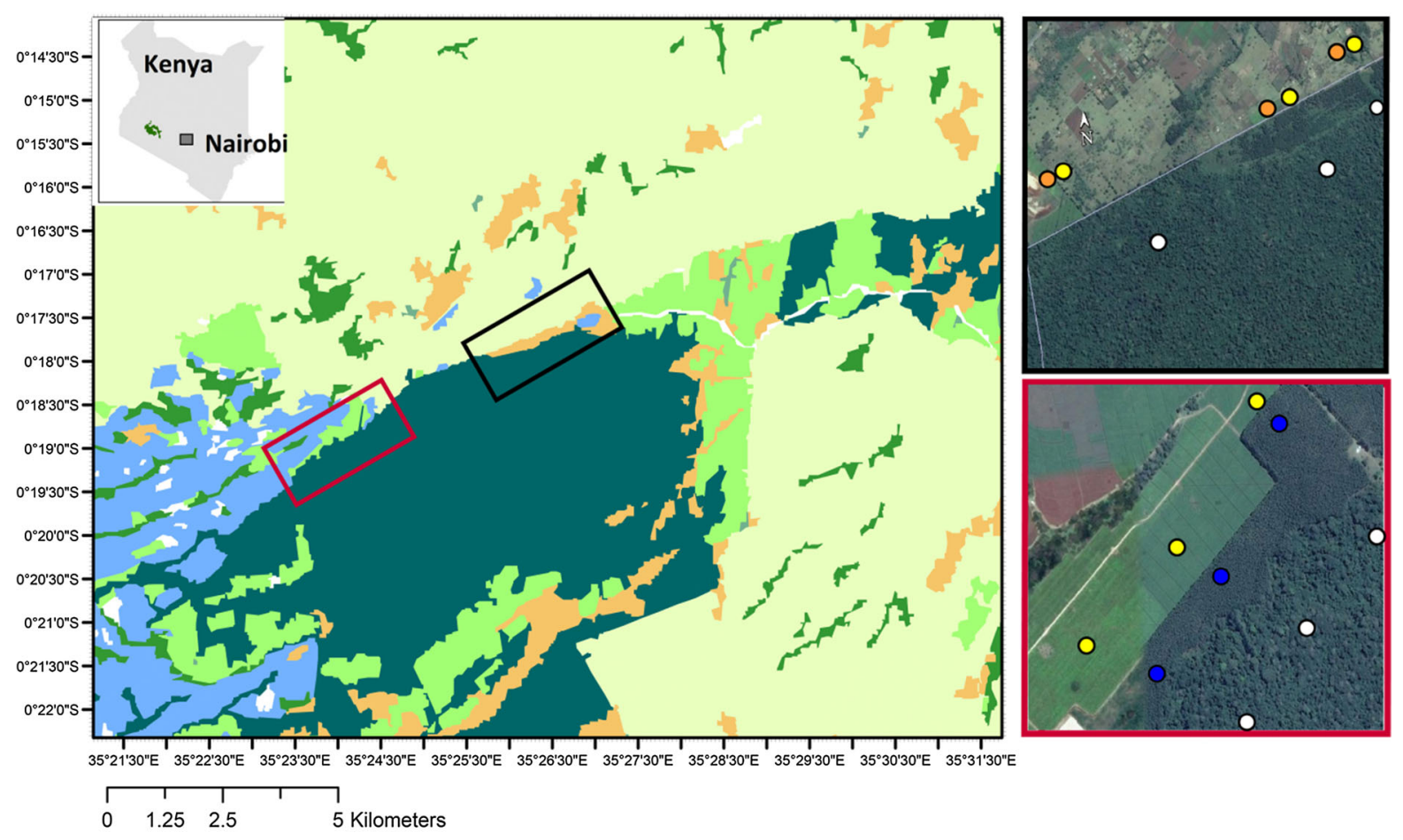

Land-uses

\begin{tabular}{|l}
\hline Eucalyptus plantation \\
Forest \\
Grazing \\
\hline Infrastructure \\
Riparian forest \\
Tea \\
Smallholder agriculture
\end{tabular}

Sampling points
Tree plantation/ Eucalyptus
Forest
Grazing

O Tea

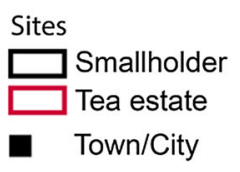

Fig. 1 Map of the study area in SW Mau forest of Kenya, area showing the two sites, smallholder area and tea estate, and the land use types where gas sampling was conducted. The two images showing sampled plots were extracted from Google Earth map@

circular plot and took inventory of all trees with a diameter at breast height $(\mathrm{DBH}=1.3 \mathrm{~m})>5 \mathrm{~cm}$ including the species name, DBH and tree height (using a Suunto clinometer). To measure the $20 \mathrm{~m}$ radius, we used the center of the plots where gas sampling was done as reference point. Tree biomass was estimated using an allometric equation developed for western Kenya tree species by Bradley (1988). The forest was disturbed due to removal of tree species of high commercial value and the setting of forest fires that increased the presence of fire-tolerant species (Kinyanjui et al. 2014). The forest plots at the tea estate site contained greater amounts of above ground biomass compared to the forest plots at the smallholder site (Table 1). The dominant tree species of the forest at the tea estate site were Croton macrostachyus Hochst. ex Ferret et Galinier and Cassipourea malosana (Bak.) Alston (90\%), while the dominant tree species at forest at the smallholder site was Neoboutonia macrocalyx Pax with scattered Syzygium guineense (Willd) DC and Syzygium cordatum Hochst. ex Krauss.

Management of the tea plantations differed between smallholders and the tea estate during the study period. For the smallholder tea plots, two of the three plots received fertilizer (NPK: $26 \% \mathrm{~N}, 5 \% \mathrm{P}_{2} \mathrm{O}_{5}$, and $5 \% \mathrm{~K}_{2} \mathrm{O}$ ) (SHT1; $125 \mathrm{~kg} \mathrm{~N} \mathrm{ha}^{-1}$ and SHT2; $40 \mathrm{~kg} \mathrm{~N} \mathrm{ha}^{-1}$ year $^{-1}$ ) (Fig. 2) that was applied by 
Table 1 Inventory of tree species abundance $\left(\# \mathrm{ha}^{-1}\right)$ and aboveground biomass (AGB) from a $20 \mathrm{~m}$ radius from the center of the forest plots (extrapolated to one hectare, $n=6$ ) sampled for $\mathrm{CO}_{2}$ and $\mathrm{CH}_{4}$ at the smallholder and tea estate sites, in the Mau forest region of, Kenya

\begin{tabular}{|c|c|c|c|c|c|c|}
\hline \multirow[t]{2}{*}{ Species } & \multicolumn{3}{|c|}{ Smallholder } & \multicolumn{3}{|c|}{ Tea Estate } \\
\hline & $\begin{array}{l}\text { SHF1 } \\
\left(\# \mathrm{ha}^{-1}\right)\end{array}$ & $\begin{array}{l}\text { SHF2 } \\
\left(\# \mathrm{Ha}^{-1}\right)\end{array}$ & $\begin{array}{l}\text { SHF3 } \\
\left(\# \mathrm{ha}^{-1}\right)\end{array}$ & $\begin{array}{l}\text { TEF1 } \\
\left(\# \mathrm{ha}^{-1}\right)\end{array}$ & $\begin{array}{l}\text { TEF2 } \\
\left.\text { (\#ha }^{-1}\right)\end{array}$ & $\begin{array}{l}\text { TEF3 } \\
\left(\# \mathrm{Ha}^{-1}\right)\end{array}$ \\
\hline Neoboutonia macrocalyx $\mathrm{Pax}$ & 63 & 589 & 621 & 71 & 31 & 40 \\
\hline Syzygium cordatum Hochst ex Krauss & 72 & - & - & 32 & - & - \\
\hline Syzygium guineense (Willd) DC. & 72 & 56 & - & - & - & - \\
\hline Prunus africana (Hook.f.) Kalkman & 151 & - & 23 & - & - & - \\
\hline Cassipourea malosana (Bak.) Alston & - & 127 & - & 215 & 406 & 446 \\
\hline Podocarpus falcatus (Thunb.) R. Br. ex Mirb. & - & 24 & 103 & - & - & 16 \\
\hline Euphorbia tirucalli $\mathrm{L}$. & - & - & 48 & 104 & - & - \\
\hline Croton macrostachyus Hochst. ex Ferret et Galinier & - & - & - & 374 & 326 & 215 \\
\hline Zanthoxylumus ambarense (Engl.) J.O. Kokwaro & - & - & - & - & 16 & - \\
\hline Celtis africana N.L. Burm. & - & - & - & - & 16 & 10 \\
\hline Tree density $\left(\#\right.$ ha $\left.^{-1}\right)$ & 358 & 796 & 795 & 796 & 795 & 727 \\
\hline Above ground biomass (AGB) $\left(\mathrm{Mg} \mathrm{ha}^{-1}\right)$ & 102 & 269 & 204 & 337 & 409 & 298 \\
\hline Mean AGB & $192 b$ & & & $348 \mathrm{a}$ & & \\
\hline
\end{tabular}

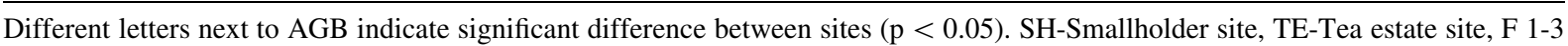
are forest plots

placing fertilizer granules around the tea plants. At the tea estate, fertilizer (NPK) was broadcasted at the onset of the rainy season to all three replicate plots at rate of $150 \mathrm{~kg} \mathrm{~N}^{-1}$ year $^{-1}$ (plots TET1 and TET3) and $250 \mathrm{~kg} \mathrm{~N} \mathrm{ha}^{-1}$ year $^{-1}$ (plot TET2) (Fig. 3). For the smallholder grazing plots, stocking densities were highly variable, ranging from 66 head ha $^{-1}$ (SHG2), to 26 head ha $^{-1}$ (SHG1) to 1.3 head ha $^{-1}$ (SHG3), this high variability is typical in smallholder farming around the Mau forest (Brandt et al. 2018). Management of livestock in these grazing plots was also quite variable: in SHG1 and SHG2 cattle were kept in the paddocks for approximately $12 \mathrm{~h}$ per day for 4-5 months of the year. These cattle were grazed in communal lands off the farms and returned to the paddocks in the evening. In contrast, plot SHG3 consisted of a large area (39 ha) where 41 cattle grazed continuously through the year. Further information on plot history is reported by Wanyama et al. (2018).

Soil sampling and analysis

Soil samples were taken from depths $0-0.05 \mathrm{~m}$, $0.05-0.2 \mathrm{~m}$ and $0.2-0.3 \mathrm{~m}$ at five randomly selected points within each plot using a core sampler
(Eijkelkamp Agrisearch Equipment, Giesbeek, The Netherlands). The samples were air dried at $30{ }^{\circ} \mathrm{C}$ and passed through a $2 \mathrm{~mm}$ sieve, and then analysed for soil texture, $\mathrm{pH}$, and total $\mathrm{C}$ and $\mathrm{N}$ concentration. Soil textural analyses were carried out following the hydrometer method as described by Gee and Bauder (1986). A 1:2.5 soil to deionized water slurry was used to measure soil $\mathrm{pH}$ following Jackson (1958). Total C and $\mathrm{N}$ (TC and TN) analyses were carried out on powdered soils (Retsch ball mill, Haan, Germany) using an elemental combustion system (ECS 4010, Costech Instruments, Italy). Soil organic carbon and nitrogen stocks (SOC and SON) were calculated using methods described by Baustista et al. (2016). Soil bulk density was determined on separate samples collected with Eijkelkamp rings by drying the known volume of soil at $105{ }^{\circ} \mathrm{C}$ to constant weight.

Inorganic $\mathrm{N}$ concentrations were determined on samples collected bi-weekly during the gas sampling campaign. Within each sampled plot, a fresh composite soil sample was collected, comprised of three subsamples (0 to $0.05 \mathrm{~m}$ depth) from three points near the chamber frames using a sharpened-edge PVC cylinder (0.05 $\mathrm{m}$ height and inner diameter). Plant litter was removed, and the fresh sample was mixed thoroughly. 
Fig. 2 Mean $( \pm \mathrm{SE}, \mathrm{n}=3)$ soil carbon dioxide (a), soil methane fluxes

(b) measured bi-weekly (August 2015 to December 2015) and weekly

(December 2016 to August 2016), and quantity and timing of fertilization $(\mathrm{kg} \mathrm{N}$ $\mathrm{ha}^{-1}$ ) applied to two tea plots (SHT1 and SH2), water filled pore space (\%WFPS) and precipitation (grey bars) (c) and soil temperature (d) from forest, grazing and tea land use types at the smallholder site (SH) in the South West Mau forest area, Kenya

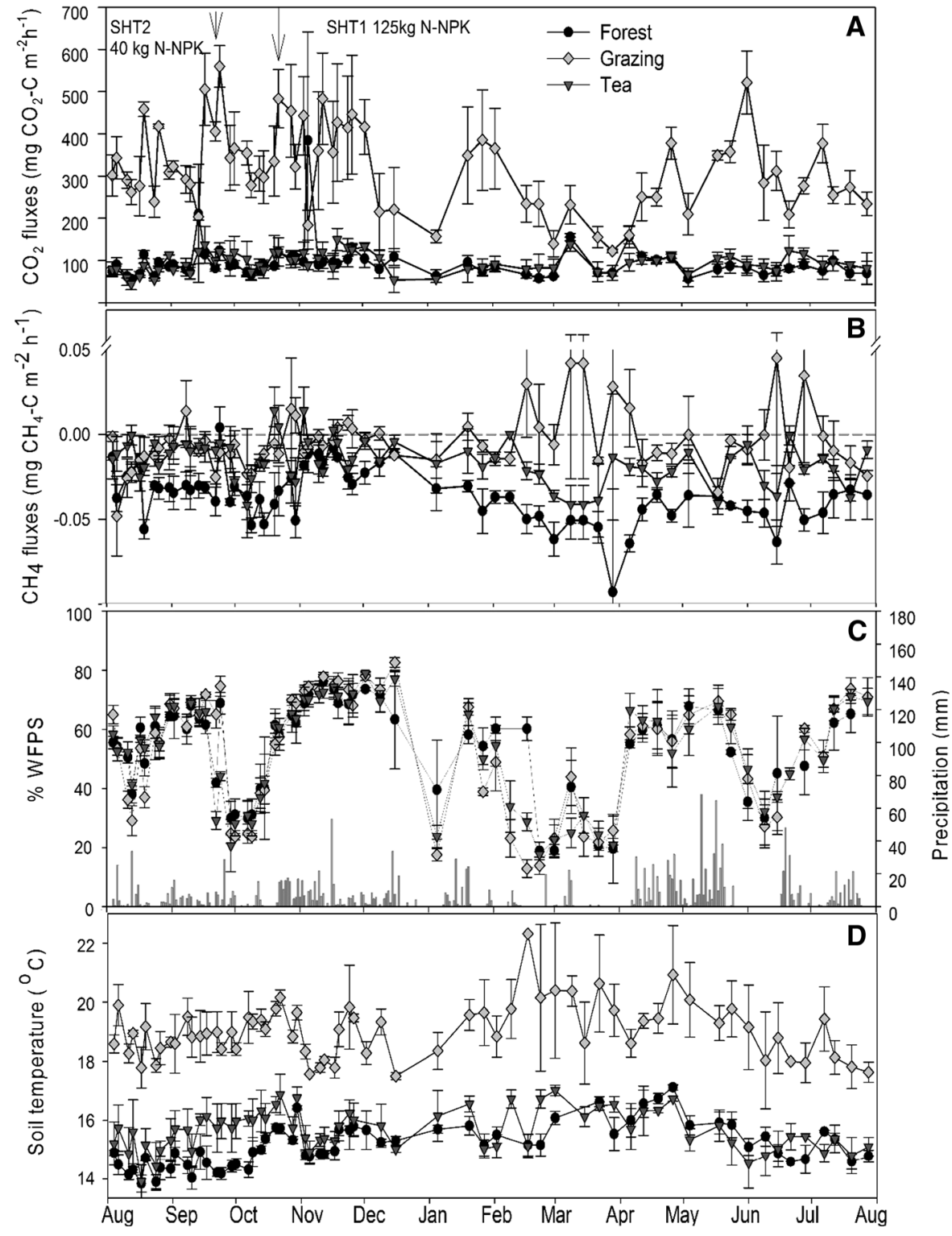

Inorganic $\mathrm{N}$ extractions were carried out on approximately $10 \mathrm{~g}$ of the homogenous fresh soil sample using $50 \mathrm{ml}$ of $0.5 \mathrm{M} \mathrm{K}_{2} \mathrm{SO}_{4}$, in a plastic bottle. The slurry was shaken for $1 \mathrm{~h}$ on a reciprocating shaker and then filtered through $110 \mathrm{~mm}$ Whatman ${ }^{\mathrm{TM}}$ number 1 filter paper enhanced with a vacuum pump to speed the process. Further filtering was done using a $0.45 \mu \mathrm{m}$ syringe filter (Minisart ${ }^{\circledR}$, Sartorius Stedim Biotech Gmbh, Goettingen, Germany) to remove finer particles. Blank samples were also prepared and used for correction during calculations. The extracts were frozen immediately until analysis. Analyses for
$\mathrm{NH}_{4}{ }^{+}-\mathrm{N}$ and $\mathrm{NO}_{3}{ }^{-}-\mathrm{N}$ were done using an Epoch ${ }^{\mathrm{TM}}$ micro-plate spectrophotometer (BioTek ${ }^{\circledR}$ Instruments, Inc., Winooski, USA). The remaining composite fresh soil sample was oven dried at $105{ }^{\circ} \mathrm{C}$ until constant soil weight to determine soil water content, thereafter inorganic $\mathrm{N}$ (IN) was calculated on dry soil mass basis. Annual cumulative $\mathrm{NH}_{4}{ }^{+}$and $\mathrm{NO}_{3}{ }^{-}$was calculated by integrating the area under respective curves and herein referred to as $\mathrm{NH}_{4}{ }^{+}-\mathrm{N}$ intensity and $\mathrm{NO}_{3}{ }^{-}-\mathrm{N}$ intensity, respectively (Burton et al. 2008; Wanyama et al. 2018). 
Fig. 3 Mean $( \pm \mathrm{SE}, \mathrm{n}=3)$ soil carbon dioxide (a), soil methane fluxes

(b) measured bi-weekly (August 2015 to December 2015) and weekly

(December 2016 to August 2016), and quantity and timing of fertilization $(\mathrm{kg} \mathrm{N}$ $\mathrm{ha}^{-1}$ ) applied to three tea plantations (TET1, TET2 and TET3), water filled pore space (\%WFPS) and precipitation (grey bars) (c) and soil temperature (d) from forest, grazing and tea land use types at the Tea Estate site (TE) in the South West Mau forest area, Kenya

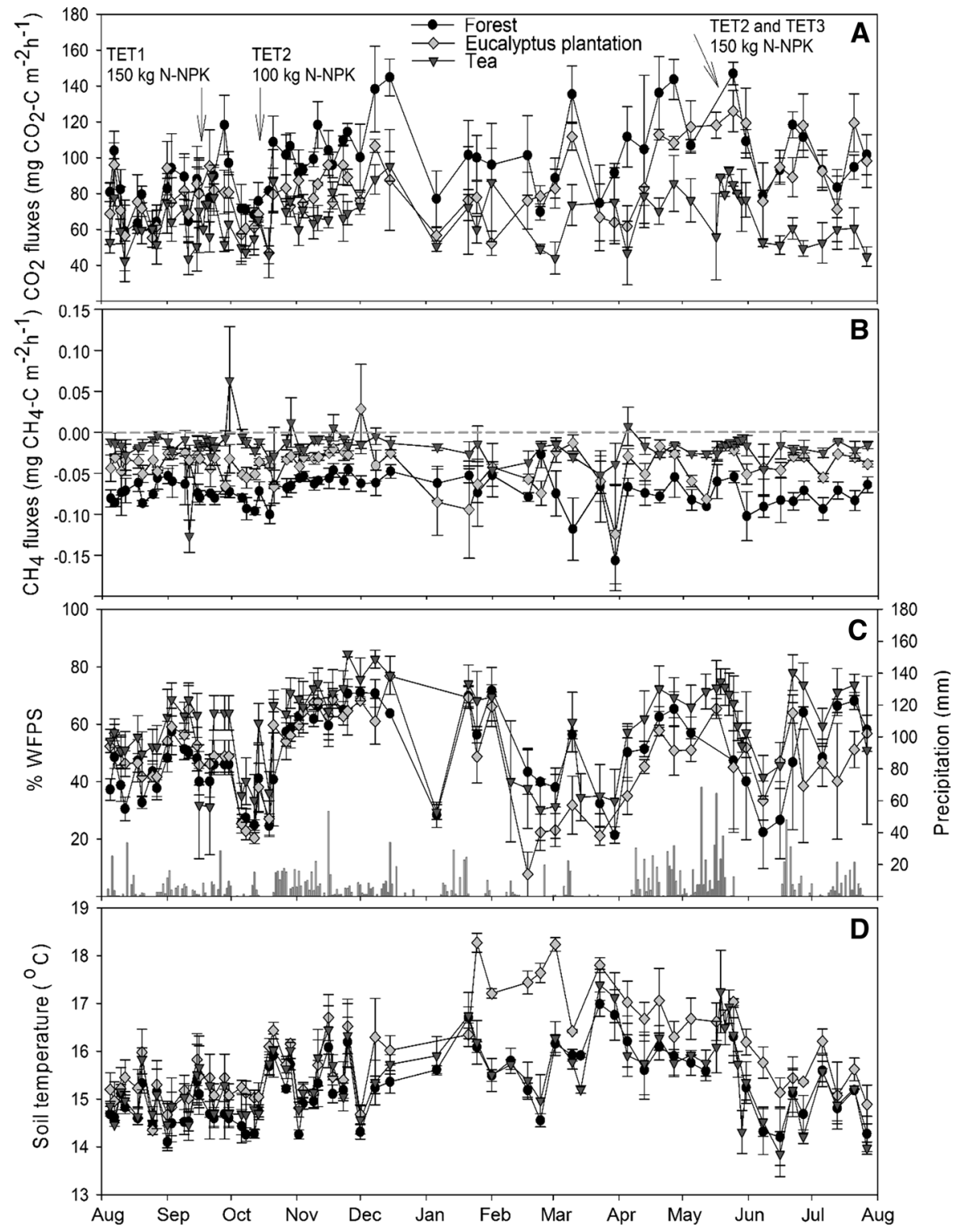

Gas sampling and analysis

We collected $\mathrm{CO}_{2}$ and $\mathrm{CH}_{4}$ gas samples for a period of 1 year using static (non-flow-through, non-steady state) opaque chambers. For each of the selected plots, five PVC frames with a basal area of $0.0875 \mathrm{~m}^{2}$ were inserted in the soil (approximately $0.07 \mathrm{~m}$ deep) a month prior to gas sampling. A ventilated PVC chamber fitted with a fan, a non-forced vent and a sampling port were attached to the PVC frame by metal clamps during sampling. Closed-foam between frame and chamber ensured airtight sealing. Gas sampling campaigns were usually run between $08 \mathrm{~h} 00$ and $11 \mathrm{~h} 30$. During chamber closure we took gas samples immediately and at 15, 30, and 45 min after closing. We used the composite sampling procedure of Arias-Navarro et al. (2013) for each plot. These authors found a marginal deviation of $2-8 \%$ for $\mathrm{CO}_{2}$ and $3-4 \%$ for $\mathrm{N}_{2} \mathrm{O}$ of pooled gas fluxes compared to individually analyzed samples. This difference between sampling procedures is small and together with the reduced costs of analyses and reduced requirements for sampling justify pooling gas samples from different chambers within a plot. During gas 
sampling using the pooling approach, $10 \mathrm{ml}$ of gas was drawn from each chamber with a $60 \mathrm{ml}$ syringe at each sampling time to attain a $50 \mathrm{ml}$ composite gas sample (from the five chambers in each selected plot). Twenty-five $\mathrm{ml}$ of the $50 \mathrm{ml}$ were used to flush a $10 \mathrm{ml}$ standard glass vial (closed with a rubber septum), while the remaining $25 \mathrm{ml}$ was forced into the flushed vial. Samples were then sent to the Mazingira Centre at the International Livestock Research Institute (ILRI) for analysis. Gas samples were analyzed within a week of sampling using a gas chromatograph equipped with a flame ionization detector (GC, SRI 8610C) for analysis of $\mathrm{CO}_{2}$ (after passage through a methanizer) and $\mathrm{CH}_{4}$, as described by Schindlbacher et al. (2004). In the $\mathrm{GC}, \mathrm{CO}_{2}$ is first converted to $\mathrm{CH}_{4}$ by a methanizer before detection by the FID. Fluxes were calculated using linear regression between the time of chamber deployment and the change in gas concentrations. Fluxes were corrected for actual air temperature and pressure measured at the time of sampling using the ideal gas law. There were a few cases where concentration of $\mathrm{CO}_{2}$ at the last sampling time was lower than the previous time $(<2 \%$ of the data). In these cases, we excluded the last data point and calculated the fluxes based on the linear increase in concentration during the first three samplings. Daily fluxes were calculated by multiplying the measured hourly flux by 24 , given that fluxes measured between 08:30 and 11:20 were found to be representative of the mean daily flux (Yang et al. 2017). Sampling in the morning hours has been shown to minimise the effect of soil temperature in soil respiration (Jian et al. 2018). Research in forests and in rangelands in Kenya showed a negligible effect of soil temperature on $\mathrm{CH}_{4}$ fluxes (Werner et al. 2007; Zhu et al. 2018). Fluxes were calculated using linear regression between the time of chamber deployment and the change in gas concentrations. In all cases, measurements were inspected, and data flagged when the measurements were not stable or unreliable: a) we excluded data with a negative $\mathrm{CO}_{2}$ flux, b) we set logical bounds for $\mathrm{CH}_{4}$ uptake (e.g. $-200 \mu \mathrm{g} \mathrm{CH}_{4}-\mathrm{C}$ $\left.\mathrm{m}^{-2} \mathrm{~h}^{-1}\right)$ and for emissions $\left(<1 \mathrm{mg} \mathrm{CH} \mathrm{CH}_{4}-\mathrm{C} \mathrm{m}^{-2}\right.$ $\mathrm{h}^{-1}$ ). Annual fluxes were calculated by linear interpolation of daily fluxes and integrating area under the curve. Linear interpolation between sampling dates is a commonly used approach in estimation of cumulative annual GHG fluxes (Parkin and Kaspar 2004; Rowlings et al. 2012), which given the weekly sampling and the low coefficient of variation of the mean daily flux rates should provide an estimate of the cumulative flux rates that is $\pm 10 \%$ of the true value (Barton et al. 2015).

\section{Statistical analysis}

Repeated measures analysis of variance using generalized least square (GLS) ANOVA (Pékar and Brabec 2016) was used to assess the effect of land use and time (fixed factors) on soil $\mathrm{CO}_{2}$ and $\mathrm{CH}_{4}$ fluxes. The GLS model included an autoregressive structure, accommodated for unequal time of sampling and a variance function that allows for unequal variance in the fixed factors, this structure was the best fit in all cases. The effect of land use and soil properties on annual $\mathrm{CO}_{2}$ and $\mathrm{CH}_{4}$ fluxes were tested using a fixed factor linear model with nlme R package (R Core Team 2016). In the models, land use and block were the fixed factors. Residual distributions for the models were examined and data were $\log$ or Johnson-transformed where necessary. Dry and wet seasons were defined by a threshold in soil moisture (40\% WFPS), comparisons of $\mathrm{CO}_{2}$ and $\mathrm{CH}_{4}$ fluxes between dry and wet periods (season) were done using the nlme package with season as the fixed factor for each of the land uses at the two sites. Simple linear regression was used to assess how the spatial and temporal variation of $\mathrm{CO}_{2}$ and $\mathrm{CH}_{4}$ were influenced by soil temperature and soil water content for each site and within each land use, as well as variation of annual $\mathrm{CO}_{2}$ and $\mathrm{CH}_{4}$ fluxes and soil properties (Total nitrogen (TN), Total carbon (TC), C:N ratio, clay content and bulk density (BD), $\mathrm{pH})$.

Stepwise multiple regression analyses were carried out using annual $\mathrm{CO}_{2}$ and $\mathrm{CH}_{4}$ fluxes as response variables and soil temperature, WFPS, soil $\mathrm{pH}, \mathrm{BD}$, $\mathrm{C}: \mathrm{N}$ ratio, inorganic $\mathrm{N}$ intensities and significant $(p<0.05)$ interactions as response variables. For soil $\mathrm{pH}, \mathrm{C}: \mathrm{N}$ ratio and $\mathrm{BD}$ we used weighed averages for the three depths $(0-0.05 \mathrm{~m}, \quad 0.05-0.2 \mathrm{~m}$ and $0.2-0.3 \mathrm{~m}$ ). We tested for multicolinearity between the independent variables and interaction terms using the variance inflation factor (VIF) in the car $R$ package. VIF values between 1 and 5 implied that the correlation between the variables was low and did not warrant correction. In case of multicollinearity between independent variables (VIF $>5$ ), standardization of the variables by subtracting means from the 
values of the independent variables was carried out and models re-run using the standardized sets. The normality, linearity and homogeneity of the model's residuals plots was also tested. In this analysis we did not include $\mathrm{CO}_{2}$ fluxes from grazing land use. In all the other land use types we report soil respiration, however in the grazing lands we did not remove the grass inside the chambers and therefore the $\mathrm{CO}_{2}$ fluxes include soil respiration and plant respiration.

\section{Results}

Soil properties, temperature and soil moisture

Soil properties varied among the land use types from the sampled soil depths $(0-0.05,0.05-0.2$ and 0.2-0.3 m) and at both sites (Table 2). All land use types across both sites had clay-textured soils (0-0.3 m depth). The C:N ratio was highest for the tea plantations while the forest $\mathrm{C}: \mathrm{N}$ ratio was lowest for all soil depths. Soil $\mathrm{pH}$ ranged from 3.8 to 6.6, with the lowest $\mathrm{pH}$ observed in the tea plots at the tea estate site. Soil BD was highest under grazing land and lowest under forest at all soil depths. $\mathrm{NH}_{4}{ }^{+}-\mathrm{N}$ intensities were higher in the tea than the forest $(\mathrm{p}=0.016)$ and eucalyptus $(\mathrm{p}<0.001)$ land use types at the tea estate site. However, variation in $\mathrm{NH}_{4}{ }^{+}-\mathrm{N}$ intensities within land use types, especially for the tea plots at the smallholder site, was high as indicated by a coefficient of variation (CV) of $99 \%$ (Table 3 ). The high CV \% corresponded with the high variability in management (fertilizer application) between the three smallholder tea plots (Table 7 in Appendix).

At the smallholder site, topsoil temperatures were highest in the grazing plots $\left(18.8^{\circ} \mathrm{C}\right)$, higher than in the tea $\left(15.7^{\circ} \mathrm{C}\right)$ and forest plots $\left(15.2^{\circ} \mathrm{C}\right)(\mathrm{p}<0.001$ for both). At the tea estate site, topsoil temperatures under eucalyptus were highest (Figs. 2d; 3d), and mean annual topsoil temperature in the eucalyptus plots $\left(15.9^{\circ} \mathrm{C}\right)$ was greater $(\mathrm{p}=0.01)$ than in the forest soils $\left(15.2^{\circ} \mathrm{C}\right)$. Temporal variation in soil temperature within a land use was small with standard deviations ranging between 0.65 and $0.99{ }^{\circ} \mathrm{C}$. Soil moisture in the topsoil $(0-0.05 \mathrm{~m})$ ranged from about $20 \%$ WFPS during the dry season to about $80 \%$ WFPS during periods with heavy rains. Mean annual WFPS was higher in grazing land at the smallholder site and in the tea plantations at the tea estate site (Figs. 2c; $3 c)$.

\section{Carbon dioxide fluxes}

Across all sites and plots, $\mathrm{CO}_{2}$ fluxes from soil varied between 42 and $559 \mathrm{mg} \mathrm{CO}-\mathrm{C} \mathrm{m}^{-2} \mathrm{~h}^{-1}$ (Figs. 2b, $3 c)$. In most treatments, the highest $\mathrm{CO}_{2}$ fluxes were observed during the wet period (Table 4), with the largest difference between periods observed for tea (27\%), followed by eucalyptus plantations $(25 \%)$ and forest $(20 \%)$ at the tea estate site. At the smallholder site the differences between land use types were smaller (18-20\%). Annual $\mathrm{CO}_{2}$ fluxes ranged from 6.0 to $31.4 \mathrm{Mg} \mathrm{CO}_{2}-\mathrm{C} \mathrm{ha}^{-1}$ year $^{-1}$ and $5.0-9.3 \mathrm{Mg} \mathrm{CO}_{2}-$ $\mathrm{C} \mathrm{ha}{ }^{-1}$ year $^{-1}$ at the smallholder and tea estate sites, respectively (Table 3 ). Mean annual $\mathrm{CO}_{2}$ fluxes at the smallholder site were highest $(\mathrm{p}=0.028)$ for grazing land $\left(25.6 \pm 2.9 \mathrm{Mg} \mathrm{CO}_{2}-\mathrm{C} \mathrm{ha}^{-1}\right.$ year $\left.^{-1}\right)$, while the mean annual soil $\mathrm{CO}_{2}$ fluxes from tea and forest plots ranged between 6.0 and 9.0 $\mathrm{Mg} \mathrm{CO}_{2}-\mathrm{C} \mathrm{ha}^{-1}$ year $^{-1}$ and were similar $(\mathrm{p}=0.875)$. At the tea estate, annual $\mathrm{CO}_{2}$ fluxes were highest $(\mathrm{p}<0.001)$ for the forest followed by eucalyptus plantations with the lowest fluxes coming from the tea plots.

\section{Methane fluxes}

Methane fluxes ranged between -0.16 and $0.06 \mathrm{mg}$ $\mathrm{CH}_{4}-\mathrm{C} \mathrm{m}^{-2} \mathrm{~h}^{-1}$ at both sites. Forest soils at both sites acted predominantly as sinks for atmospheric $\mathrm{CH}_{4}$, with approximately $92 \%$ of the measurements indicating net $\mathrm{CH}_{4}$ uptake (Figs. 2a, 3a). Eucalyptus plantations (91\% of measurements) and tea plantations ( $73 \%$ of measurements) were also predominantly $\mathrm{CH}_{4}$ sinks, whereas only $47 \%$ of the measurements in grazing lands showed $\mathrm{CH}_{4}$ uptake. For all land use types except for the smallholder grazing site, $\mathrm{CH}_{4}$ uptake was significantly higher during the dry than during the wet periods: $43 \%$ higher for tea, and $30 \%$ higher for forest at the smallholder site, and 64, 35, and $27 \%$ higher for the tea, eucalyptus and native forest, respectively, at the tea estate site (Table 4).

Annual cumulative $\mathrm{CH}_{4}$ fluxes ranged between - 6.61 and $0.08 \mathrm{~kg} \mathrm{CH}_{4}-\mathrm{C} \mathrm{ha}^{-1}$ year $^{-1}$ and apart from one grazing plot (SHG1), soils at all plots acted as net sinks for atmospheric $\mathrm{CH}_{4}$ (Table 3). The highest $\mathrm{CH}_{4}$ uptakes at both sites occurred in the forest soils, which were $41-88 \%$ higher than the uptake at 


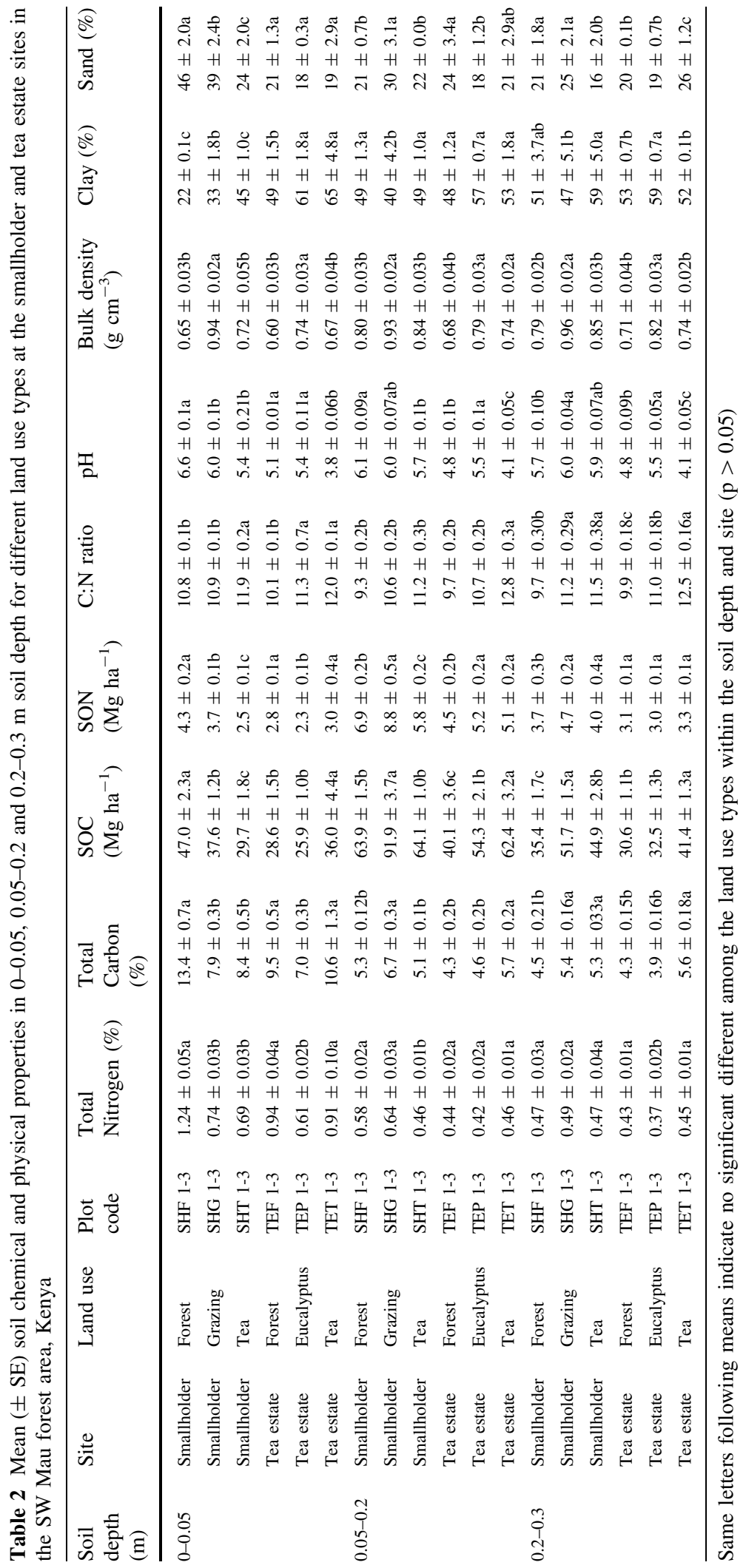




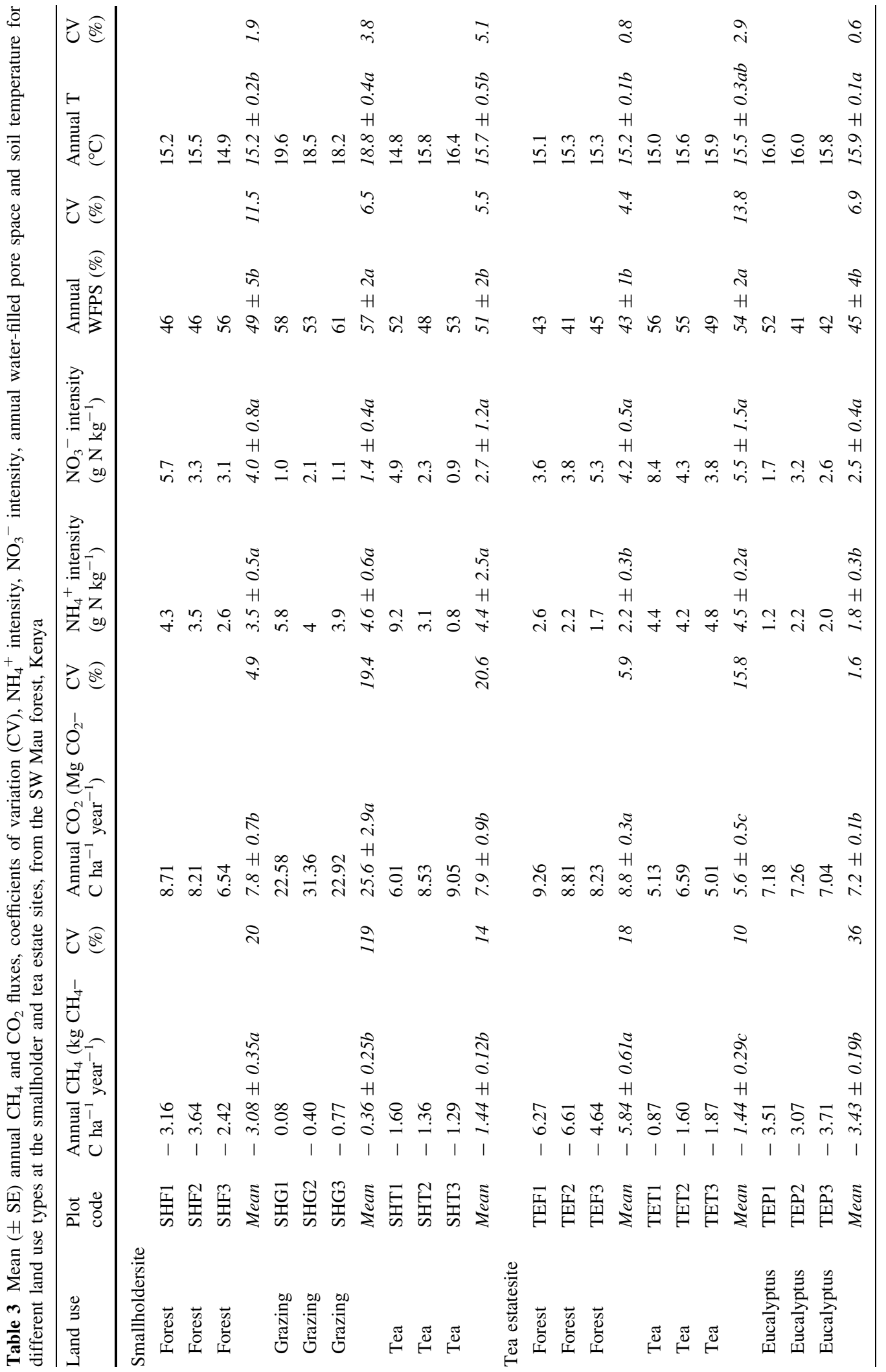


Table 4 Average daily $\mathrm{CH}_{4}$ and $\mathrm{CO}_{2}$ fluxes for three different land use types in the two study sites (smallholders and tea estate) calculated for the wet and dry periods

\begin{tabular}{|c|c|c|c|c|c|c|c|c|}
\hline \multirow[t]{2}{*}{ Site } & \multirow[t]{2}{*}{ Land use } & \multirow[t]{2}{*}{ Plot code } & \multicolumn{2}{|c|}{$\begin{array}{l}\text { Daily } \mathrm{CH}_{4} \text { fluxes }\left(\mathrm{mg} \mathrm{CH}_{4}-\mathrm{C} \mathrm{m}^{-2}\right. \\
\left.\mathrm{h}^{-1}\right)\end{array}$} & \multirow[t]{2}{*}{$p$ value } & \multicolumn{2}{|c|}{$\begin{array}{l}\text { Daily } \mathrm{CO}_{2} \text { fluxes }\left(\mathrm{mg} \mathrm{CO} \mathrm{CO}_{2}-\mathrm{C}\right. \\
\left.\mathrm{m}^{-2} \mathrm{~h}^{-1}\right)\end{array}$} & \multirow[t]{2}{*}{ p-value } \\
\hline & & & Wet & Dry & & Wet & Dry & \\
\hline Smallholder & Forest & SHF 1-3 & $-0.029 \pm 0.001$ & $-0.042 \pm 0.004$ & $<0.001$ & $98.9 \pm 5.4$ & $79.5 \pm 3.8$ & $<0.001$ \\
\hline Smallholder & Grazing & SHG 1-3 & $-0.006 \pm 0.002$ & $0.001 \pm 0.007$ & 0.20 & $335.9 \pm 11.9$ & $271.9 \pm 17.8$ & $<0.001$ \\
\hline Smallholder & Tea & SHT 1-3 & $-0.013 \pm 0.001$ & $-0.023 \pm 0.003$ & $<0.001$ & $97.8 \pm 3.2$ & $79.9 \pm 5.9$ & 0.002 \\
\hline Tea estate & Forest & TEF $1-3$ & $-0.058 \pm 0.005$ & $-0.079 \pm 0.004$ & $<0.001$ & $104.1 \pm 2.7$ & $82.7 \pm 2.7$ & $<0.001$ \\
\hline Tea estate & Eucalyptus & TEP 1-3 & $-0.028 \pm 0.006$ & $-0.043 \pm 0.003$ & $<0.001$ & $90.7 \pm 2.2$ & $67.4 \pm 3.1$ & $<0.001$ \\
\hline Tea estate & Tea & TET $1-3$ & $-0.009 \pm 0.003$ & $-0.025 \pm 0.003$ & $<0.001$ & $71.7 \pm 1.6$ & $52.2 \pm 2.7$ & $<0.001$ \\
\hline
\end{tabular}

Water filled pore space (WFPS) of $40 \%$ was used to define the seasons

other land use types $(\mathrm{p}=0.007$ for smallholder and $\mathrm{p}=0.008$ for tea estate). There was high variability of annual $\mathrm{CH}_{4}$ fluxes in the grazing plots $(\mathrm{CV}=119 \%)$, where annual $\mathrm{CH}_{4}$ fluxes ranged between $-0.77 \mathrm{~kg}$ $\mathrm{CH}_{4}-\mathrm{C} \mathrm{ha}^{-1}$ year $^{-1}$ and $0.08 \mathrm{~kg} \mathrm{CH}_{4}-\mathrm{C} \mathrm{ha}^{-1}$ year $^{-1}$. Plots with high grazing densities tended to be sources of $\mathrm{CH}_{4}$, while the plot with low grazing density (SHG3) exhibited greater $\mathrm{CH}_{4}$ uptake. At the tea estate, cumulative $\mathrm{CH}_{4}$ uptake among the land use types decreased $(p=0.008)$ in the following order; forest $>$ eucalyptus plantation $>$ tea plantation.

Effect of environmental variables on $\mathrm{CO}_{2}$ and $\mathrm{CH}_{4}$ fluxes

Variation of soil $\mathrm{CO}_{2}$ fluxes with instantaneous WFPS was low, with instantaneous WFPS explaining at most $22 \%$ of the variation among the land use types at both sites. As there was little variability in instantaneous soil temperatures within plots, we found that the soil temperature influence on $\mathrm{CO}_{2}$ fluxes was also weak $\left(\mathrm{R}^{2}\right.$ values ranging between 0.01 and 0.31 ). As with the $\mathrm{CO}_{2}$ fluxes, the contribution of soil temperature to the instantaneous variation of soil $\mathrm{CH}_{4}$ fluxes was small, ranging between 0.3 and $9 \%$ (Table 5). The strongest relationship $\left(\mathrm{R}^{2}=0.25\right)$ between instantaneous WFPS and $\mathrm{CH}_{4}$ was observed in soils of forest plots at the smallholder site; the other land use types exhibited weaker relationship with $\mathrm{R}^{2}$ values ranging between 0.02 and 0.11 . Our measurements of annual $\log$ transformed $\mathrm{CO}_{2}$ fluxes were positively correlated with soil $\mathrm{pH} \quad(0-0.3 \mathrm{~m}$ soil depth $) \quad(\mathrm{p}=0.03$, $\left.\mathrm{R}^{2}=0.52\right)$ and negatively correlated with the soil $\mathrm{C}: \mathrm{N}$ ratio $\left(\mathrm{p}=<0.001, \mathrm{R}^{2}=0.28\right)$. Stepwise linear regression showed that $\left(\log _{10}\right)$ soil $\mathrm{CO}_{2}$ fluxes were influenced by soil $\mathrm{pH}(\mathrm{pH})$, weighted bulk density (BD), and that this relationship explained $60.6 \%$ of the variation. Addition of the interaction between soil $\mathrm{pH}$ and soil $\mathrm{C}: \mathrm{N}$ ratio (Eq. 1) to the model significantly $(p=0.005)$ improved the relationship to $83.4 \%$ $(\mathrm{p}=<0.001)$ (Table 6).

$$
\begin{aligned}
\log _{10}\left(\mathrm{CO}_{2}\right)= & 1.49+0.06 \times \mathrm{pH}-0.79 \times \mathrm{BD} \\
& -0.005 \times \mathrm{C}: \mathrm{N}+0.04 \\
& \times(\mathrm{pH} \times \mathrm{C}: \mathrm{N})
\end{aligned}
$$

Annual $\mathrm{CH}_{4}$ uptake from all the land use types decreased with increases in mean annual WFPS $\left(\mathrm{R}^{2}=0.60\right) \quad($ Fig. $4 \mathrm{a}), \mathrm{NH}_{4}{ }^{+}$intensity $\left(\mathrm{R}^{2}=0.30\right)$ (Fig. 4b), C:N ratio $\left(\mathrm{R}^{2}=0.30\right.$ ) (Fig. 4c) and bulk density $\left(R^{2}=0.43\right)$ at all soil depths (Fig. $\left.4 d\right)$. Results from stepwise regression (Eq. 2) show that $\mathrm{CH}_{4}$ was driven by ammonium intensity $\left(\mathrm{NH}_{4}{ }^{+}-\mathrm{N}\right), \log$ WFPS, $\mathrm{BD}$ and soil $\mathrm{C}: \mathrm{N}$ ratio and these factors explained $79.5 \%$ ( $\mathrm{p} \leq 0.001)$ of the total variation, the contribution of each variable to the variation is shown in Table 6.

$$
\begin{aligned}
\mathrm{CH}_{4}= & -37.9+0.27 \times \mathrm{NH}_{4}^{+}-\mathrm{N}+13.7 \\
& \times \log _{10}(\text { WFPS })+0.48 \times \mathrm{C}: \mathrm{N}+7.7 \times \mathrm{BD}
\end{aligned}
$$

\section{Discussion}

The mean annual soil respiratory $\mathrm{CO}_{2}$ fluxes from the forests in this study $(7.5 \pm 0.2$ and $8.8 \pm 3.3 \mathrm{Mg}$ $\mathrm{CO}_{2}-\mathrm{C} \mathrm{ha}{ }^{-1}$ year $^{-1}$, for smallholder and tea estate sites, respectively) were similar to soil fluxes from a 
Table 5 Model statistics for the linear relationships $(\mathrm{y}=\mathrm{a}+\mathrm{bx})$ between daily $\mathrm{CH}_{4}, \mathrm{CO}_{2}$ and environmental variables: soil temperature and water filled pore space (WFPS) for land use types at two sites in the Mau forest area, Kenya

\begin{tabular}{|c|c|c|c|c|c|c|c|c|c|}
\hline Site & GHG Gas & Variable & Land use & Plot code & Slope (b) & Intercept (a) & $\mathrm{R}^{2}$ & $\mathrm{n}$ & $\mathrm{p}$-value \\
\hline \multirow[t]{3}{*}{ Smallholder } & \multirow[t]{12}{*}{$\mathrm{CH}_{4}$} & \multirow[t]{6}{*}{ Temperature } & Forest & SHF 1-3 & -0.008 & 0.09 & 0.31 & 166 & $<0.001$ \\
\hline & & & Grazing & SHG 1-3 & 0.003 & -0.070 & 0.02 & 164 & 0.08 \\
\hline & & & Tea & SHT 1-3 & -0.001 & 0.002 & 0.005 & 163 & 0.38 \\
\hline \multirow[t]{3}{*}{ Tea estate } & & & Forest & TEF 1-3 & -0.0033 & -0.019 & 0.004 & 180 & 0.43 \\
\hline & & & Plantation & TEP 1-3 & -0.0088 & 0.107 & 0.03 & 168 & 0.04 \\
\hline & & & Tea & TET $1-3$ & -0.009 & 0.128 & 0.03 & 177 & 0.02 \\
\hline \multirow[t]{3}{*}{ Smallholder } & & \multirow[t]{6}{*}{ WFPS } & Forest & SHF 1-3 & 0.0008 & -0.007 & 0.25 & 175 & $<0.001$ \\
\hline & & & Grazing & SHG 1-3 & -0.0001 & 0.002 & 0.008 & 189 & 0.24 \\
\hline & & & Tea & SHT 1-3 & 0.0002 & -0.028 & 0.04 & 180 & 0.006 \\
\hline \multirow[t]{3}{*}{ Tea estate } & & & Forest & TEF 1-3 & 0.0007 & -0.010 & 0.11 & 186 & $<0.001$ \\
\hline & & & Plantation & TEP $1-3$ & 0.0009 & -0.074 & 0.06 & 178 & 0.001 \\
\hline & & & Tea & TET $1-3$ & 0.0005 & -0.034 & 0.02 & 182 & 0.05 \\
\hline \multirow[t]{3}{*}{ Smallholder } & \multirow[t]{6}{*}{$\mathrm{CO}_{2}$} & \multirow[t]{6}{*}{ Temperature } & Forest & SHF 1-3 & 10.18 & -66.5 & 0.09 & 171 & $<0.001$ \\
\hline & & & Grazing & SHG 1-3 & -11.1 & 527.8 & 0.01 & 172 & 0.143 \\
\hline & & & Tea & SHT 1-3 & 14.27 & -131.4 & 0.15 & 176 & $<0.001$ \\
\hline \multirow[t]{3}{*}{ Tea estate } & & & Forest & TEF $1-3$ & 13.3 & -104.8 & 0.13 & 166 & $<0.001$ \\
\hline & & & Plantation & TEP 1-3 & 6.05 & -11.6 & 0.05 & 165 & 0.003 \\
\hline & & & Tea & TET $1-3$ & 5.2 & -11.8 & 0.06 & 245 & $<0.001$ \\
\hline \multirow[t]{3}{*}{ Smallholder } & & \multirow[t]{6}{*}{ WFPS } & Forest & SHF 1-3 & 0.224 & 77.9 & 0.01 & 185 & 0.120 \\
\hline & & & Grazing & SHG 1-3 & 1.563 & 231.6 & 0.05 & 188 & $<0.001$ \\
\hline & & & Tea & SHT 1-3 & 0.74 & 56.9 & 0.08 & 185 & $<0.001$ \\
\hline \multirow[t]{3}{*}{ Tea estate } & & & Forest & TEF 1-3 & 1.01 & 52.0 & 0.22 & 174 & $<0.001$ \\
\hline & & & Plantation & TEP 1-3 & 0.63 & 54.9 & 0.12 & 184 & $<0.001$ \\
\hline & & & Tea & TET 1-3 & 0.46 & 44.1 & 0.08 & 182 & $<0.001$ \\
\hline
\end{tabular}

Table 6 Summary results from multiple regression between annual gas fluxes $\left(\mathrm{CO}_{2}\right.$ and $\left.\mathrm{CH}_{4}\right)$ and soil properties: $\mathrm{pH}$ soil $\mathrm{pH}$, $B D$ bulk density, $C: N$ soil $\mathrm{C}: \mathrm{N}$ ratio, $p H^{*} C: N$ interaction term

\begin{tabular}{|c|c|c|c|c|c|}
\hline Gas flux & Variables & Coefficients & $\mathrm{F}$ value & p-value & $\%$ of total variance \\
\hline \multirow[t]{5}{*}{$\log \mathrm{CO}_{2}$} & Intercept & 1.49 & & $<0.001$ & \\
\hline & $\mathrm{pH}$ & 0.060 & 18.3 & 0.002 & 30.3 \\
\hline & $\mathrm{BD}$ & -0.79 & 18.3 & 0.002 & 30.3 \\
\hline & $\mathrm{C}: \mathrm{N}$ & -0.005 & 0.58 & 0.463 & 1.0 \\
\hline & $\mathrm{pH}^{*} \mathrm{C}: \mathrm{N}$ & 0.04 & 13.3 & 0.005 & 21.9 \\
\hline \multirow[t]{5}{*}{$\mathrm{CH}_{4}$} & Intercept & -37.9 & & 0.001 & \\
\hline & $\mathrm{NH}_{4}^{+}$ & 0.27 & 16.4 & 0.002 & 28.1 \\
\hline & $\log _{10}(\mathrm{WFPS})$ & 13.7 & 23.1 & $<0.001$ & 39.5 \\
\hline & $\mathrm{C}: \mathrm{N}$ & 0.48 & 1.4 & 0.256 & 2.4 \\
\hline & $\mathrm{BD}$ & 7.7 & 5.5 & 0.036 & 9.5 \\
\hline
\end{tabular}

soil $\mathrm{pH}$ and soil $\mathrm{C}: \mathrm{N}$ ratio; $\mathrm{NH}_{4}^{+}$soil ammonium concentration, $\log _{10}$ (WFPS) water filled pore space 

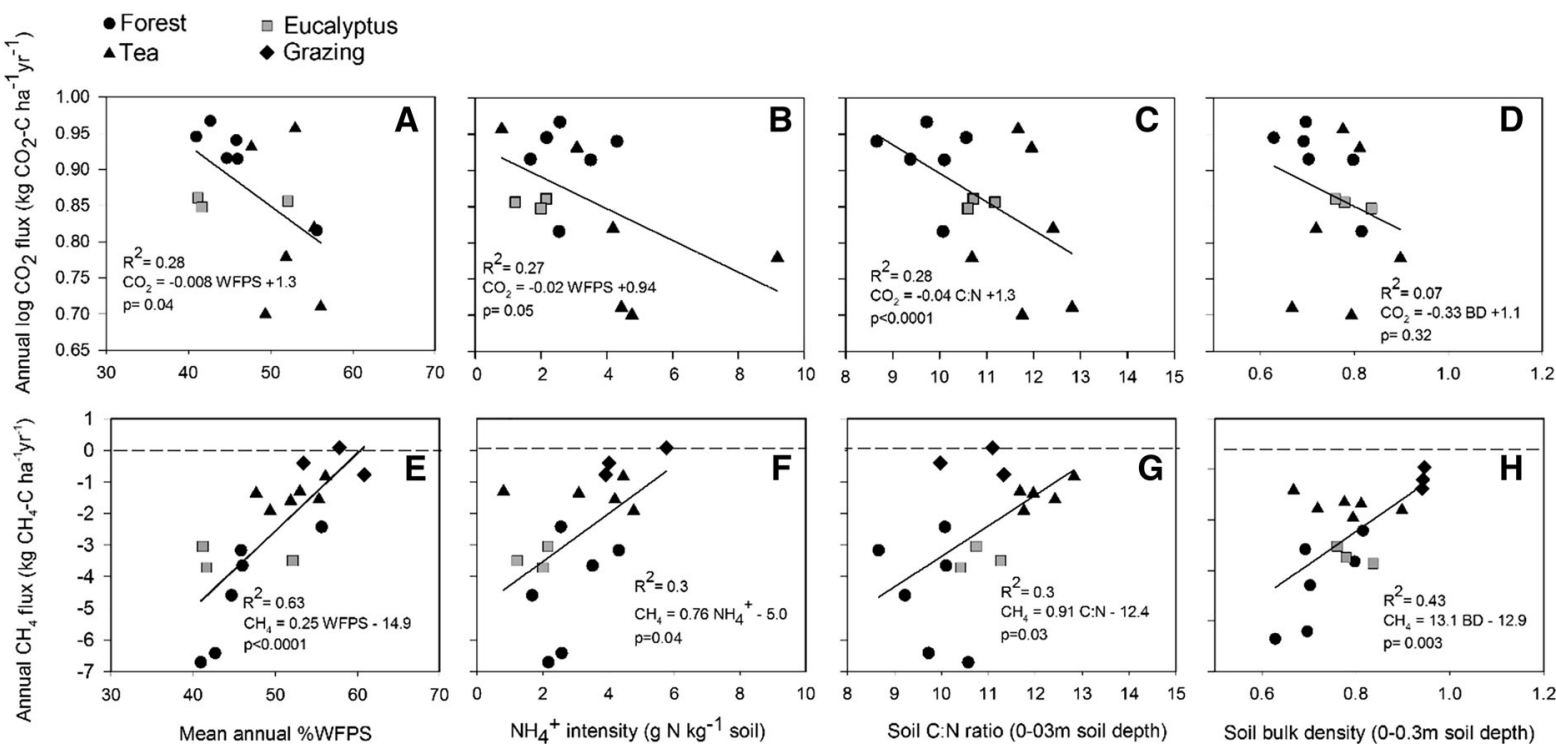

Fig. 4 Linear relationship between annual log transformed $\mathrm{CO}_{2}\left(\mathrm{Mg} \mathrm{CO}_{2}-\mathrm{Cha}^{-1}\right.$ year $\left.{ }^{-1}\right)$ and $\mathrm{CH}_{4}$ fluxes $\left(\mathrm{kg} \mathrm{CH}_{4}-\mathrm{Cha}^{-1}\right.$ year ${ }^{-1}$ ) fluxes with $(\mathbf{a}, \mathbf{e})$ mean annual water filled pore space (\%WFPS), (b, f) ammonium $\left(\mathrm{NH}_{4}{ }^{+}\right)$intensity, $(\mathbf{c}, \mathbf{g})$ weighted

tropical montane forest in China $(6.85 \pm 3.4 \mathrm{Mg}$

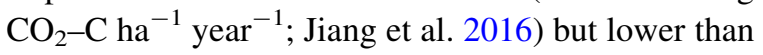
those from soils of a grazed Afromontane forest (15.7 to $19.4 \mathrm{Mg} \mathrm{CO}_{2}-\mathrm{C} \mathrm{ha}^{-1}$ year $^{-1}$ ) in Ethiopia (Yohannes et al. 2011). The annual soil respiratory $\mathrm{CO}_{2}$ fluxes from the grazing lands of our study $\left(25.6 \mathrm{Mg} \mathrm{CO}_{2}-\mathrm{C}\right.$ $\mathrm{ha}^{-1}$ year $^{-1}$ ) were higher than those measured in other tropical grazing lands; with previous studies measuring soil annual $\mathrm{CO}_{2}$ fluxes that ranged from 5.2 to 11.2 $\mathrm{Mg} \mathrm{CO} \mathrm{CO}_{2}-\mathrm{C} \mathrm{ha}{ }^{-1}$ year $^{-1}$ for western Kenya (Pelster et al. 2017), 13.4 to $15.0 \mathrm{Mg} \mathrm{CO}_{2}-\mathrm{C}^{-1-}$ $\mathrm{yr}^{-1}$ for grazing lands in the Kenyan highlands (Rosenstock et al. 2016) and 10 to $15 \mathrm{Mg} \mathrm{CO}_{2}-\mathrm{C}$ $\mathrm{ha}^{-1}$ year $^{-1}$ for grazing lands in eastern Amazonia, Brazil (Davidson et al. 2000). The higher soil $\mathrm{CO}_{2}$ fluxes from the grazing lands in our study were also much higher than fluxes from all other land use types. These higher $\mathrm{CO}_{2}$ fluxes are not directly comparable to these other studies, so that microbial respiration plus aboveground and belowground plant and soil respiration were likely measured. At all other sites (tea and eucalyptus plantations and the natural forest) soils were bare without ground cover, so that only microbial plus root respiration were measured. A study by Zhu et al. (2015) in grasslands in China reported that soil $\mathrm{CO}_{2}$ fluxes from ecosystem respiration, i.e. including plant respiration, were approximately double the

(0-30 cm depth) C:N ratio and (d, h) weighted (0-30 cm depth) soil bulk density (b) from soils of forest, tea, grazing and eucalyptus plantations land use types at the smallholder and tea estate sites, in the SW Mau forest area of Kenya

fluxes from soil respiration alone. In addition, Pennisetum clandestinum, the dominant grass species in the grazing plots in our sites, is a $\mathrm{C} 4$ grass that produces relatively greater amounts of root exudates that result in higher rates of root respiration compared to tea and eucalyptus which use C3 photosynthetic pathways (Roberts and Keys 1978; Leuning et al. 1991; Chen et al. 2016). Furthermore, the soil carbon concentrations $(7.1 \%)$ in the $0-0.2 \mathrm{~m}$ soil layer of the grazing lands in our study were 2-3 times higher than in the grazing lands in the study by Pelster et al. (2017) $(2.3 \%)$ and that by Rosenstock et al. (2016) (2.2-3.7\%) with similar bulk densities, which could partly explain the higher soil $\mathrm{CO}_{2}$ fluxes in our study.

Strong responses of soil $\mathrm{CO}_{2}$ to soil temperature have been reported in studies where variations in soil temperature are wide, for instance in a study by Fan et al. (2015) at a forest site exposed to a subtropical monsoon climate in Eastern China, with soil temperatures varying over the year in a range of 0 to $35^{\circ} \mathrm{C}$. However, variations in soil temperature in our study region were smaller than the variation in temperate zones (ranging between 14 and $18{ }^{\circ} \mathrm{C}$ for the forest, tea plantations, eucalyptus plantations and croplands, and ranging between 17 and $22{ }^{\circ} \mathrm{C}$ for the grazing lands). The $\mathrm{Q}_{10}$ value of soil respiration was found to be approximately 2.4 (Raich and Schlesinger 1992), 
meaning that a $10{ }^{\circ} \mathrm{C}$ increase in temperature can cause a 2.4-fold increase in soil respiration. The threefold increase in $\mathrm{CO}_{2}$ flux in the grazing plots from a 2 to $2.5{ }^{\circ} \mathrm{C}$ increase in soil temperature suggests a $\mathrm{Q}_{10}$ value of approximately 12 , which is inconsistent with previous studies, suggesting that the variation in fluxes was most likely due to other factors.

Soil respiratory $\mathrm{CO}_{2}$ fluxes were explained by soil $\mathrm{pH}, \mathrm{C}: \mathrm{N}$ ratio, bulk density as well as the interaction between soil $\mathrm{pH}$ and $\mathrm{C}: \mathrm{N}$ ratio. Soil $\mathrm{pH}$ moderates microbial activities through which $\mathrm{CO}_{2}$ is produced (Treseder 2008). Cuhel et al. (2010) found that the highest soil $\mathrm{CO}_{2}$ emissions occurred around neutral soil $\mathrm{pH}$. Our data showed spatial variation in soil $\mathrm{pH}$ and this can be attributed to management activities such as application of inorganic fertilizers in the tea plots. In combination with soil $\mathrm{C}: \mathrm{N}$ ratio, soil $\mathrm{pH}$ explained the greatest portion of variation in $\mathrm{CO}_{2}$ fluxes. Soil C:N ratios indicate the ease with which SOC is decomposed by soil microbes, thus lower C:N ratios lead to higher soil $\mathrm{CO}_{2}$ fluxes (Sylvia et al. 2005). Bulk density influenced negatively $\mathrm{CO}_{2}$ fluxes, likely because the higher $\mathrm{BD}$ is associated with less pore space, reducing gas diffusivity through the soil (Fujikawa and Miyazaki 2005), resulting in less gaseous exchange between soil and atmosphere.

Tropical forest soils within our study area acted predominantly as sinks for atmospheric $\mathrm{CH}_{4}$, similarly to previous studies summarized by Veldkamp et al. (2013), Dalal and Allen (2008) and Dutaur and Verchot (2007). Annual $\mathrm{CH}_{4}$ fluxes at the natural forest plots of the smallholder site $\left(-3.2 \mathrm{~kg} \mathrm{CH}_{4}-\mathrm{C}\right.$ $\mathrm{ha}^{-1}$ year $^{-1}$ ) were comparable to annual $\mathrm{CH}_{4}$ fluxes observed for tropical montane forests soils in Ecuador (-3.1 kg CH $4-\mathrm{C} \mathrm{ha}^{-1}$ year $^{-1}$; Wolf et al. 2012) and Tanzania (range -2.7 to $-3.9 \mathrm{~kg} \mathrm{CH}_{4}-\mathrm{C} \mathrm{ha}^{-1}$ year $^{-1}$; Gütlein et al. 2017), but higher than those found for a montane forest in Indonesia $(-1.5 \mathrm{~kg}$ $\mathrm{CH}_{4}-\mathrm{C} \mathrm{ha}^{-1}$ year $^{-1}$; Purbopuspito et al. 2006). The lower soil uptake $\mathrm{CH}_{4}$ rates $\left(-1.5 \mathrm{~kg} \mathrm{CH}_{4}-\mathrm{C}^{-1}\right.$ year $^{-1}$ ) in the study by Purbopuspito et al. (2006) were due to a very thick organic layer at the soil surface, which not only hampered gas diffusion but might have also stimulated $\mathrm{CH}_{4}$ production. The annual $\mathrm{CH}_{4}$ uptake rates of the natural forest soils at the tea estate site were greater $\left(-5.9 \mathrm{~kg} \mathrm{CH}_{4}-\mathrm{C} \mathrm{ha}^{-1}\right.$ year $\left.^{-1}\right)$ than those measured in the studies from montane tropical environments mentioned above, but similar to the annual flux rate reported for the Kakamega rainforest in Kenya ( $-4.8 \mathrm{~kg} \mathrm{CH}_{4}-\mathrm{C}^{-1}$ year $^{-1}$; Werner et al. 2007), which is at a lower elevation (1530 m asl.), but with similar soil texture as our sites.

Our study showed reductions in $\mathrm{CH}_{4}$ uptake by soils converted to other land use types compared to native forest soils. Converted land use types in our study were characterized by livestock trampling in grazing lands, tillage during land preparation and trampling by humans and vehicular traffic in tea and eucalyptus plantations. All of these activities were observed to change the soil hydrologic properties (Owuor et al. 2018), which can alter $\mathrm{CH}_{4}$ production and consumption. The increased soil bulk density and higher water content measured in the tea and eucalyptus plantations and grazing lands reduced oxygen and $\mathrm{CH}_{4}$ diffusion and increased occurrence of anaerobic conditions in the soil so that the observed net $\mathrm{CH}_{4}$ uptake at the soil surface decreases as $\mathrm{CH}_{4}$ production is stimulated while $\mathrm{CH}_{4}$ oxidation decreases (Jacinthe et al. 2014). The cumulative $\mathrm{CH}_{4}$ uptake in our study was negatively correlated with both WFPS and soil bulk density, also indicating that reduced oxygen diffusion and increased incidence of anaerobiosis result in a promotion of $\mathrm{CH}_{4}$ production at the cost of uptake. The contribution of soil water content (WFPS) and bulk density explained over $49 \%$ of the total variation in soil $\mathrm{CH}_{4}$ fluxes (Table 6). This is consistent with Smith et al. (2000), who observed a steady decrease in $\mathrm{CH}_{4}$ uptake with increasing soil bulk density and soil water content.

Soil $\mathrm{CH}_{4}$ uptake rates were negatively correlated with $\mathrm{NH}_{4}{ }^{+}-\mathrm{N}$ intensity, i.e. $\mathrm{CH}_{4}$ uptake decreased with increasing $\mathrm{NH}_{4}{ }^{+}-\mathrm{N}$ availability. The inhibition of methanotrophic activity by increased availability of $\mathrm{NH}_{4}{ }^{+}$has been explained not only by the competition of $\mathrm{CH}_{4}$ and $\mathrm{NH}_{4}{ }^{+}$for the methane mono-oxygenase enzyme, which catalyzes the conversion of $\mathrm{CH}_{4}$ to $\mathrm{CO}_{2}$ and can also oxidize $\mathrm{NH}_{4}{ }^{+}$to nitrite (Bédard and Knowles 1989), but also by toxic effects of intermediates and endproducts of $\mathrm{NH}_{4}{ }^{+}$oxidation (i.e. hydroxylamin and nitrite) on methanotropic avtivity (Bodelier and Laanbroek 2004). Heavy grazing of cattle also leads to increased bulk densities, reduced gas diffusion and increased abundance and activity of methanogenic archaea (Radl et al. 2007; Kim et al. 2014). Both effects have been shown to lead to increased $\mathrm{CH}_{4}$ production in the soil (Ho et al. 2015), which might also explain reduced rates of $\mathrm{CH}_{4}$ uptake in the grazing plots in this study. Some studies 
observed increased $\mathrm{CH}_{4}$ uptake with increasing temperature (Schaufler et al. 2010) in upland soils, as such we expected high methane uptake in grazing lands but this was not the case in our study. This is likely due to fact that methane uptake is in most cases primarily governed by gas diffusion (Dutaur and Verchot 2007) and the effect of temperature was likely masked by in gas diffusion limitations.

Strong seasonal patterns for both soil $\mathrm{CO}_{2}$ and $\mathrm{CH}_{4}$ fluxes were observed (Table 4), which reflect the influence of soil moisture on the fluxes. The wet season at our study sites was characterised as period when soil moisture contents were between 41 and $85 \%$ WFPS. A soil core study by Arias-Navarro et al. (2017b) at the same site reported soil $\mathrm{CO}_{2}$ fluxes increased with increasing WFPS up to a moisture level of $90 \%$. Also in other studies soil $\mathrm{CO}_{2}$ fluxes increased with increasing soil water content up to a maximum flux at field capacity (Schaufler et al. 2010). Methane uptake was highest during the dry period, this is expected as lower soil moisture content during the dry period facilitates gas diffusion and an aerobic environment under which methane uptake is high (Dutaur and Verchot 2007).

The soil fluxes measured in the forest may not have captured the high spatial variability driven by differences in elevation (Jones et al. 2016). For example, in a previous study in the Mau forest, it was shown that soil $\mathrm{CO}_{2}$ fluxes were dependent on slope position and varied significantly at scales of 10-100 m (AriasNavarro et al. 2017a). In our study neither elevation nor slope effects on soil $\mathrm{CO}_{2}$ fluxes were studied. Additionally, we only measured fluxes for one soil type in one agro-ecological zone, while in the mountainous Mau forest region various soil types can be found and rainfall varies on short distance due to elevation and exposition effects (Kinyanjui et al. 2014). Our study is however, the first empirical assessment of atmospheric $\mathrm{C}$ exchange on the soil/vegetation to atmosphere interface before and after forest conversion to the dominant land use types of this montane ecosystem.

\section{Conclusion}

Our study is the first of its kind reporting on in situ $\mathrm{CO}_{2}$ and $\mathrm{CH}_{4}$ fluxes from forest and converted land use types in the Mau forest of Kenya. Soil respiratory $\mathrm{CO}_{2}$ fluxes were influenced by land use with the converted land use types, with the exception of the grazing lands, generally exhibiting lower soil $\mathrm{CO}_{2}$ fluxes compared to natural forests. Methane uptake by soils was significantly reduced in managed land compared to soils of natural forests. This indicates that conversion of forest reduces the potential of soil to consume atmospheric $\mathrm{CH}_{4}$ in tropical montane regions. Reduction in $\mathrm{CH}_{4}$ consumption was mainly related to reduction in gas diffusion as reflected by soil water content and bulk density. The importance of changes in soil bulk density and soil moisture regime indicate that gas diffusion was the main driver of spatial $\mathrm{CH}_{4}$ fluxes. For both gasses, we observed differences in fluxes between forests and the converted land use types indicating that land use significantly affect fluxes for the two GHG. These spatial changes can be linked to management practices such as tillage, grazing intensity and $\mathrm{N}$ fertilization in the converted land uses. While our study provides the first estimates on the effect of land use on soil $\mathrm{CO}_{2}$ and $\mathrm{CH}_{4}$ fluxes in the Mau forest (the largest contiguous tropical montane forest in east Africa), additional measurements comparing fluxes from different land use types on other soil types in different climate zones of these montane forests are needed to provide a thorough understanding of how land use change has affected soil $\mathrm{CO}_{2}$ and $\mathrm{CH}_{4}$ fluxes in forest ecosystems of this region.

Acknowledgements We thank the Climate Change, Agriculture and Food Security (CCAFS) and Forests, Trees and Agro-forestry (FTA) programs under the CGIAR for funding this work, and the IFAD project "Greening livestock: Incentive-based interventions for reducing the climate impact of livestock production in East Africa" for additional support. Ibrahim Wanyama received a doctoral research grant from the DAAD; grant number A/13/94827. We acknowledge the Kenya Forest Service for allowing us to carry out this research in the Mau forest. Lastly, we thank the farmers of the Mau region for allowing us to work in their fields, and the field staff who worked with us during the sampling.

Open Access This article is distributed under the terms of the Creative Commons Attribution 4.0 International License (http:// creativecommons.org/licenses/by/4.0/), which permits unrestricted use, distribution, and reproduction in any medium, provided you give appropriate credit to the original author(s) and the source, provide a link to the Creative Commons license, and indicate if changes were made.

\section{Appendix}

See Table 7. 


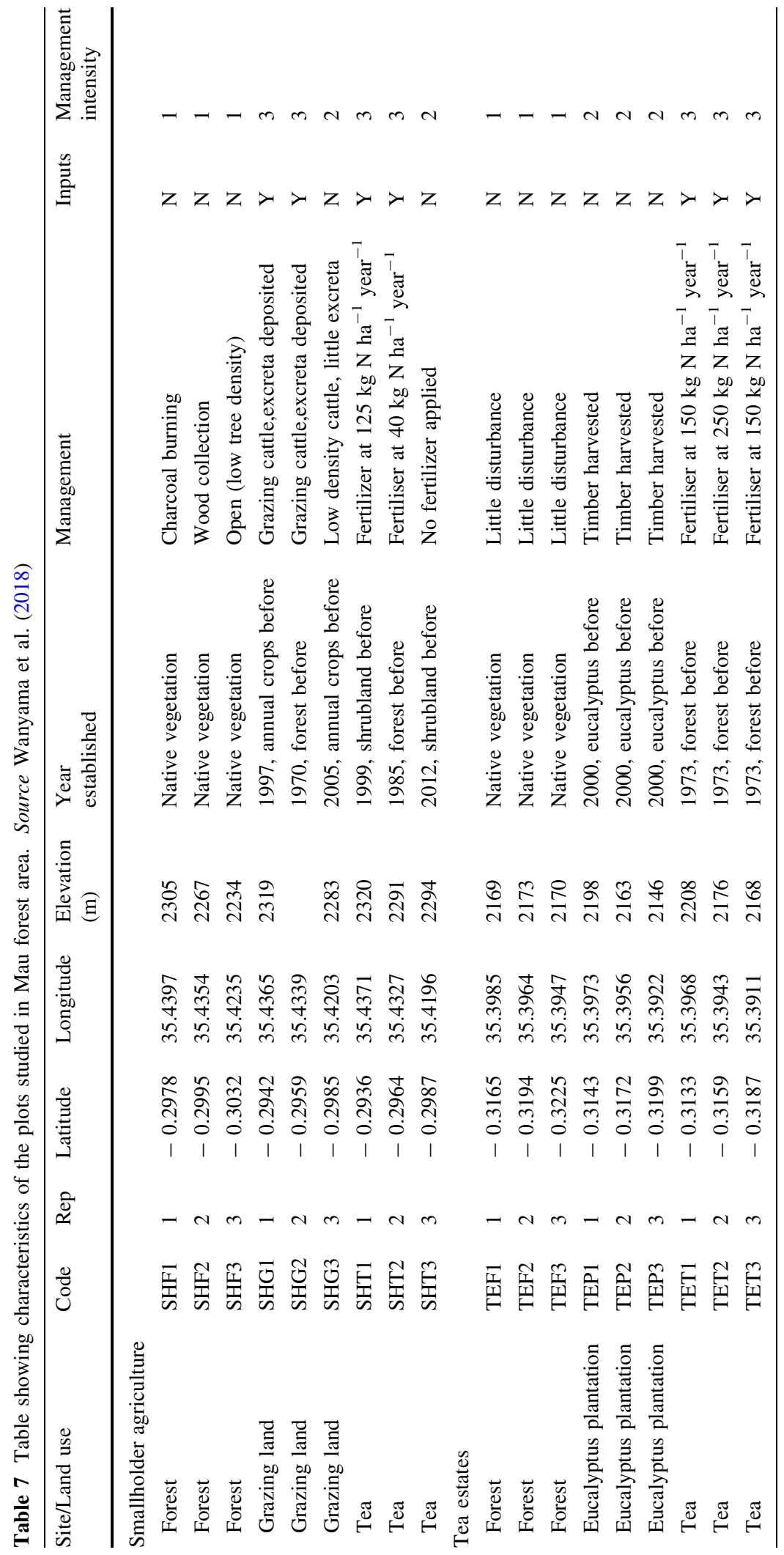




\section{References}

Adachi M, Ito A, Yonemura S et al (2017) Estimation of global soil respiration by accounting for land-use changes derived from remote sensing data. J Environ Manage 200:97-104. https://doi.org/10.1016/j.jenvman.2017.05.076

Arevalo C, Bhatti JS, Chang SX et al (2010) Soil respiration in four different land use systems in north central Alberta. Canada. J Geophys Res-Biogeosci 115(G1):1-12. https:// doi.org/10.1029/2009jg001006

Arias-Navarro C, Díaz-Pinés E, Kiese R et al (2013) Gas pooling: a sampling technique to overcome spatial heterogeneity of soil carbon dioxide and nitrous oxide fluxes. Soil Biol Biochem 67:20-23. https://doi.org/10. 1016/j.soilbio.2013.08.011

Arias-Navarro C, Díaz-Pinés E, Klatt S et al (2017a) Spatial variability of soil $\mathrm{N}_{2} \mathrm{O}$ and $\mathrm{CO}_{2}$ fluxes in different topographic positions in a tropical montane forest in Kenya. J Geophys Res-Biogeosci 122:514-527. https://doi.org/10. 1002/2016JG003667

Arias-Navarro C, Diaz-Pines E, Zuazo P et al (2017b) Quantifying the contribution of land use to $\mathrm{N}_{2} \mathrm{O}$, $\mathrm{NO}$ and $\mathrm{CO}_{2}$ fluxes in a montane forest ecosystem of Kenya. Biogeochemistry 134:95-114. https://doi.org/10.1007/s10533017-0348-3

Baldyga TJ, Miller SN, Driese KL et al (2008) Assessing land cover change in Kenya's Mau Forest region using remotely sensed data. Afr J Ecol 46:46-54. https://doi.org/10.1111/j. 1365-2028.2007.00806.x

Barton L, Wolf B, Rowlings D et al (2015) Sampling frequency affects estimates of annual nitrous oxide fluxes. Sci RepUK 5(15912):1-9. https://doi.org/10.1038/srep15912

Baustista F, Garcia E, Gallegos A (2016) The App SOC plus a tool to estimate and calculate organic carbon in soil profile. J Appl Res Technol 14:135-139. https://doi.org/10.1016/j. jart.2016.03.002

Bédard C, Knowles R (1989) Physiology, biochemistry, and specific inhibitors of $\mathrm{CH}_{4}, \mathrm{NH}_{4}^{+}$, and $\mathrm{CO}$ oxidation by methanotrophs and nitrifiers. Microbiol Rev 53:68-84

Blackie J (1972) Hydrological effects of a change in land use from rain forest to tea plantation in Kenya. IAHS/ UNESCO Stud Rep Hydrol 12:312-329. http://hydrologie. org/redbooks/a096/097026.pdf

Bodelier PLE, Laanbroek HJ (2004) Nitrogen as a regulatory factor of methane oxidation in soils and sediments. FEMS Microbiol Ecol 47:265-277. https://doi.org/10.1016/ S0168-6496(03),00304-0

Bond-Lamberty B, Wang C, Gower ST (2004) A global relationship between the heterotrophic and autotrophic components of soil respiration? Glob Change Biol 10:1756-1766. https://doi.org/10.1111/j.1365-2486.2004. 00816.x

Bradley PN (1988) Survey of woody biomass on farms in Western Kenya. Ambio 17:40-48. www.jstor.org/stable/ 4313417

Brandt P, Hamunyela E, de Bruin S et al (2018) Sustainable intensification of dairy production can reduce forest disturbance in Kenyan montane forests. Agric Ecosyst Environ 265:307-319. https://doi.org/10.1016/j.agee.2018.06. 011
Burton D, Zebarth B, Gillam K et al (2008) Effect of split application of fertilizer nitrogen on $\mathrm{N}_{2} \mathrm{O}$ emissions from potatoes. Can J Soil Sci 88:229-239. https://doi.org/10. 4141/CJSS06007

Butterbach-Bahl K, Papen H (2002) Four years continuous record of $\mathrm{CH}_{4}$ exchange between the atmosphere and untreated and limed soil of a N-saturated spruce and beech forest ecosystem in Germany. Plant Soil 240:77-90. https://doi.org/10.1023/A:1015856617553

Chen J, Wang Q, Li M et al (2016) Does the different photosynthetic pathway of plants affect soil respiration in a subtropical wetland? Ecol Evol 6:8010-8017. https://doi. org/10.1002/ece 3.2523

Chiti T, Díaz-Pinés E, Butterbach-Bahl K et al (2018) Soil organic carbon changes following degradation and conversion to cypress and tea plantations in a tropical mountain forest in Kenya. Plant Soil 422:527-539. https://doi. org/10.1007/s11104-017-3489-1

Cuhel J, Simek M, Laughlin RJ, Bru D, Cheneby D, Watson CJ, Philippot L (2010) Insights into the effect of soil $\mathrm{pH}$ on $\mathrm{N}_{2} \mathrm{O}$ and $\mathrm{N}_{2}$ emissions and denitrifier community size and activity. Appl Environ Microb 76:1870-1878. https://doi. org/10.1128/AEM.02484-09

Dalal RC, Allen DE (2008) Greenhouse gas fluxes from natural ecosystems. Austr J Bot 56:369-407. https://doi.org/10. 1071/bt07128

Davidson EA, Janssens IA (2006) Temperature sensitivity of soil carbon decomposition and feedbacks to climate change. Nature 440:165-173. https://doi.org/10.1038/ nature 04514

Davidson EA, Verchot LV, Cattanio JH et al (2000) Effects of soil water content on soil respiration in forests and cattle pastures of eastern Amazonia. Biogeochemistry 48:53-69. https://doi.org/10.1023/A:1006204113917

Dexter AR (2004) Soil physical quality: part I. Theory, effects of soil texture, density, and organic matter, and effects on root growth. Geoderma 120:201-214. https://doi.org/10.1016/j. geoderma.2003.09.004

Dutaur L, Verchot LV (2007) A global inventory of the soil $\mathrm{CH}_{4}$ sink. Global Biogeochem Cycles 21(GB4013):1-9. https:// doi.org/10.1029/2006GB002734

Fan LC, Yang MZ, Han WY (2015) Soil respiration under different land uses in eastern China. PLoS ONE 10:e0124198. https://doi.org/10.1371/journal.pone.0124198

Fujikawa T, Miyazaki T (2005) Effects of bulk density and soil type on the gas diffusion coefficient in repacked and undisturbed soils. Soil Sci 170:892-901. https://doi.org/10. 1097/01.ss.0000196771.53574.79

Gee GW, Bauder JW (1986) Particle-size analysis. Klute A. (Ed.) Methods of soil analysis, part 1: physical and mineralogical methods. Monograph No 9, Amer Soc Agron Inc. \& Soil Sci Soc America Inc., Madison: 383-411

Ghosh A, Patra P, Ishijima K et al (2015) Variations in global methane sources and sinks during 1910-2010. Atmos Chem Phys 15:2595-2612. https://doi.org/10.5194/acp15-2595-2015

Gütlein A, Gerschlauer F, Kikoti I, Kiese R (2017) Impacts of climate and land use on $\mathrm{N}_{2} \mathrm{O}$ and $\mathrm{CH}_{4}$ fluxes from tropical ecosystems in the Mt. Kilimanjaro region, Tanzania. Glob Change Biol 24(3):1239-1255. https://doi.org/10.1111/ gcb. 13944 
Hanson P, Edwards N, Garten CT et al (2000) Separating root and soil microbial contributions to soil respiration: a review of methods and observations. Biogeochemistry 48:115-146. https://doi.org/10.1023/A:1006244819642

Hashimoto S, Carvalhais N, Ito A et al (2015) Global spatiotemporal distribution of soil respiration modeled using a global database. Biogeosciences 12:4121-4132. https:// doi.org/10.5194/bg-12-4121-201

Hassler E, Corre M, Tjoa A et al (2015) Soil fertility controls soil-atmosphere carbon dioxide and methane fluxes in a tropical landscape converted from lowland forest to rubber and oil palm plantations. Biogeosciences 12:5831-5852. https://doi.org/10.5194/bg-12-5831-2015

Hesslerova P, Pokorny J (2010) Forest clearing, water loss, and land surface heating as development costs. Int $\mathrm{J}$ Water 5:401-418. https://doi.org/10.1504/IJW.2010.038732

Ho A, El-Hawwary A, Kim Y et al (2015) Manure-associated stimulation of soil-borne methanogenic activity in agricultural soils. Biol Fertil Soils 51:511-516. https://doi.org/ 10.1007/s00374-015-0995-2

IUSS Working Group WRB (2015) World reference base for soil resources 2014, update 2015 International soil classification system for naming soils and creating legends for soil maps. Rome

Jacinthe PA, Dick A, Lal R et al (2014) Effects of no-till duration on the methane oxidation capacity of Alfisols. Biol Fertil Soils 50:477-486. https://doi.org/10.1007/ s00374-013-0866-7

Jackson ML (1958) Soil chemical analysis Hydrogen activity determination for soils, measurement of soil $\mathrm{pH}$. PrenticeHall Inc., Englewood Cliffs, pp 41-49

Jian J, Steele MK, Day SD et al (2018) Measurement strategies to account for soil respiration temporal heterogeneity across diverse regions. Soil Biol Biochem 125:167-177. https://doi.org/10.1029/2018EF000937

Jiang X, Chen H, Peng C et al (2016) Soil carbon dioxide fluxes from three forest types of the tropical montane rainforest on Hainan island. China. Water Air Soil Poll 227:213. https:// doi.org/10.1007/s11270-016-2904-1

Jones SP, Diem T, Quispe LPH et al (2016) Drivers of atmospheric methane uptake by montane forest soils in the southern Peruvian Andes. Biogeosciences 13:4151-4165. https://doi.org/10.5194/bg-13-4151-2016

Kim SY, Pramanik P, Bodelier PL et al (2014) Cattle manure enhances methanogens diversity and methane emissions compared to swine manure under rice paddy. PLoS ONE 9:e113593. https://doi.org/10.1371/journal.pone.0113593

Kim D-G, Thomas AD, Pelster D et al (2016) Greenhouse gas emissions from natural ecosystems and agricultural lands in sub-Saharan Africa: synthesis of available data and suggestions for further research. Biogeosciences 13:4789-4809. https://doi.org/10.5194/bg-13-4789-2016

Kinyanjui J (2009) The effect of human encroachment on forest cover, structure and composition in the western blocks of the Mau forest complex. Unpublished Ph.D. Thesis. Egerton University, Kenya

Kinyanjui MJ, Latva-Käyrä P, Bhuwneshwar PS et al (2014) An inventory of the above ground biomass in the Mau Forest ecosystem, Kenya. Open J Ecol 4:619-627. https://doi.org/ 10.4236/oje.2014.410052
Kirschke S, Bousquet P, Ciais P et al (2013) Three decades of global methane sources and sinks. Nat Geosci 6:813-823. https://doi.org/10.1038/ngeo1955

Kravchenko IK (2017) Microbial oxidation of atmospheric methane in natural and agricultural upland soils. In: Singh J, Seneviratne G (eds) Agro-Environmental sustainability. Springer, Cham

Leuning R, Cromer R, Rance S (1991) Spatial distributions of foliar nitrogen and phosphorus in crowns of Eucalyptus grandis. Oecologia 88:504-510. https://doi.org/10.1007/ BF00317712

Oertel C, Matschullat J, Zurba K et al (2016) Greenhouse gas emissions from soils-a review. Chem Erde 76:327-352. https://doi.org/10.1016/j.chemer.2016.04.002

Olang L, Kundu P, Ouma G et al (2014) Impacts of land cover change scenarios on storm runoff generation: a basis for management of the Nyando Basin, Kenya. Land Degrad Dev 25:267-277. https://doi.org/10.1002/ldr.2140

Owuor SO, Butterbach-Bahl K, Guzha AC et al (2018) Conversion of natural forest results in a significant degradation of soil hydraulic properties in the highlands of Kenya. Soil Till Res 176:36-44. https://doi.org/10.1016/j.still.2017.10. 003

Parkin TB, Kaspar TC (2004) Temporal variability of soil carbon dioxide flux. Soil Sci Soc Am 68(4):1234-1241. https://doi.org/10.2136/sssaj2004.1234

Pékar S, Brabec M (2016) Marginal models via GLS: a convenient yet neglected tool for the analysis of correlated data in the behavioural sciences. Ethology 122:1-11. https://doi. org/10.1111/eth.12514

Pelster D, Rufino MC, Rosenstock T et al (2017) Smallholder African farms in western Kenya have limited greenhouse gas fluxes. Biogeosciences 14:187-202. https://doi.org/10. 5194/bg-14-187-2017

Purbopuspito J, Veldkamp E, Brumme R et al (2006) Trace gas fluxes and nitrogen cycling along an elevation sequence of tropical montane forests in Central Sulawesi. Indonesia. Glob Biogeochem Cycles 20:GB3010. https://doi.org/10. 1029/2005gb002516

R Core Team (2016) R: a language and environment for statistical computing. R Foundation for Statistical Computing, Vienna, Austria

Radl V, Gattinger A, Chroňáková A et al (2007) Effects of cattle husbandry on abundance and activity of methanogenic archaea in upland soils. ISME J 1:443-452. https://doi.org/ 10.1038/ismej.2007.60

Raich JW, Schlesinger WH (1992) The global carbon dioxide flux in soil respiration and its relationship to vegetation and climate. Tellus 44:81-99. https://doi.org/10.1034/j.16000889.1992.t01-1-00001.x

Roberts G, Keys A (1978) The mechanism of photosynthesis in the tea plant (Camellia sinensis L.). J Exp Bot 29:1403-1407. https://doi.org/10.1093/jxb/29.6.1403

Rosenstock TS, Mathew M, Pelster DE et al (2016) Greenhouse gas fluxes from agricultural soils of Kenya and Tanzania. J Geophys Res-Biogeo 121:1568-1580. https://doi.org/10. 1002/2016JG003341

Rowlings DW, Grace PR, Kiese R et al (2012) Environmental factors controlling temporal and spatial variability in the soil-atmosphere exchange of $\mathrm{CO} 2, \mathrm{CH} 4$ and $\mathrm{N} 2 \mathrm{O}$ from an Australian subtropical rainforest. Global Change Biol 
18(2):726-738. https://doi.org/10.1111/j.1365-2486.2011. 02563.x

Schaufler G, Kitzler B, Schindlbacher A et al (2010) Greenhouse gas emissions from European soils under different land use: effects of soil moisture and temperature. Eur $\mathbf{J}$ Soil Sci 61:683-696. https://doi.org/10.1111/j.1365-2389. 2010.01277.x

Schindlbacher A, Zechmeister-Boltenstern S, Butterbach-Bahl $\mathrm{K}$ (2004) Effects of soil moisture and temperature on NO, $\mathrm{NO}_{2}$, and $\mathrm{N}_{2} \mathrm{O}$ emissions from European forest soils. J Geophys Res-Atmos 109:1-12. https://doi.org/10.1029/ 2004JD004590

Smith KA, Dobbie KE, Ball BC et al (2000) Oxidation of atmospheric methane in northern European soils, comparison with other ecosystems, and uncertainties in the global terrestrial sink. Glob Change Biol 6:791-803. https://doi.org/10.1046/j.1365-2486.2000.00356.x

Smith KA, Ball T, Conen F et al (2018) Exchange of greenhouse gases between soil and atmosphere: interactions of soil physical factors and biological processes. Eur J Soil Sci 69:10-20. https://doi.org/10.1111/ejss.12539

Sylvia DM, Fuhrmann JJ, Hartel PG et al (2005) Principles and applications of soil microbiology, 2nd edn. Pearson Prentice Hall, New Jersey, p 672

Treseder KK (2008) Nitrogen additions and microbial biomass: a meta-analysis of ecosystem studies. Ecol Lett 11:1111-1120. https://doi.org/10.1111/j.1461-0248.2008. 01230.x

Trotsenko YA, Khmelenina VN (2002) Biology of extremophilic and extremotolerant methanotrophs. Arch Microbiol 177:123-131. https://doi.org/10.1007/s00203-001-0368-0

Veldkamp E, Koehler B, Corre M (2013) Indications of nitrogen-limited methane uptake in tropical forest soils. Biogeosciences 10:5367. https://doi.org/10.5194/bg-10-53672013

Verchot LV, Davidson EA, Cattânio H et al (2000) Land use change and biogeochemical controls of methane fluxes in soils of Eastern Amazonia. Ecosystems 3:41-56. https:// doi.org/10.1007/s100210000009
Wanyama I, Pelster D, Arias-Navarro C et al (2018) Management intensity controls soil $\mathrm{N}_{2} \mathrm{O}$ fluxes in an Afromontane ecosystem. Sci Total Environ 624:769-780. https://doi. org/10.1016/j.scitotenv.2017.12.081

Werner C, Kiese R, Butterbach-Bahl K (2007) Soil-atmosphere exchange of $\mathrm{N} 2 \mathrm{O}, \mathrm{CH} 4$, and $\mathrm{CO} 2$ and controlling environmental factors for tropical rain forest sites in western Kenya. J Geophys Res-Atmos 112:1-15. https://doi.org/10. 1029/2006JD007388

Wolf K, Flessa H, Veldkamp E (2012) Atmospheric methane uptake by tropical montane forest soils and the contribution of organic layers. Biogeochemistry 111:469-483. https:// doi.org/10.1007/s10533-011-9681-0

Yang H, Liu S, Li Y et al (2017) Diurnal variations and gap effects of soil $\mathrm{CO}_{2}, \mathrm{~N}_{2} \mathrm{O}$ and $\mathrm{CH}_{4}$ fluxes in a typical tropical montane rainforest in Hainan Island, China. Ecol Res 33:379-392. https://doi.org/10.1007/s11284-017-1550-4

Yohannes Y, Shibistova O, Abate A et al (2011) Soil $\mathrm{CO}_{2}$ efflux in an afromontane forest of Ethiopia as driven by seasonality and tree species. For Ecol Manag 261:1090-1098. https://doi.org/10.1016/j.foreco.2010.12.032

Yu L, Huang Y, Zhang W et al (2017) Methane uptake in global forest and grassland soils from 1981 to 2010. Sci Total Environ 607:1163-1172. https://doi.org/10.1016/j. scitotenv.2017.07.082

Zhu L, Johnson DA, Wang W et al (2015) Grazing effects on carbon fluxes in a Northern China grassland. J Arid Environ 114:41-48. https://doi.org/10.1016/j.jaridenv.2014.11. 004

Zhu Y, Merbold L, Pelster DE et al (2018) Effect of dung quantity and quality on greenhouse gas fluxes from tropical pastures in Kenya. Glob Biogeochem Cycles 32:1589-1604. https://doi.org/10.1029/2018GB005949

Publisher's Note Springer Nature remains neutral with regard to jurisdictional claims in published maps and institutional affiliations. 